\title{
Research Paper \\ Requirements of a Multicultural Curriculum in Primary Education: Explaining the Features on the Basis of a Combined Approach
}

\section{Seyedeh Homa Aghili ${ }^{1}$, Majid Ali Asgari ${ }^{* 2}$, Ali Hosseinikhah ${ }^{3}$, Rezvan Hakimzadeh ${ }^{4}$, Alireza Sadeghi ${ }^{5}$}

1. Ph.D. Student of Educational Planning, Faculty of Psychology and Educational Sciences, Kharazmi University of Tehran, Iran

2. Associate Professor, Department of Curriculum Planning, Faculty of Psychology and Educational Sciences, Kharazmi University of Tehran, Iran

3. Assistant Professor, Department of Curriculum Planning, Faculty of Psychology and Educational Sciences, Kharazmi University of Tehran, Iran

4. Associate Professor, Department of Curriculum Planning, Faculty of Psychology and Educational Sciences, University of Tehran, Iran 5. Assistant Professor, Department of Curriculum Planning, Faculty of Psychology and Educational Sciences, Allameh Tabatabaei University, Tehran, Iran

Citation: Aghili S H, Ali Asgari M, Hosseinikhah A, Hakimzadeh R, Sadeghi A. Requirements of a Multicultural Curriculum in Primary Education: Explaining the Features on the Basis of a Combined Approach. J Child Ment Health. 2021; 7 (4):39-60.

\section{URL: http://childmentalhealth.ir/article-1-1007-en.html}
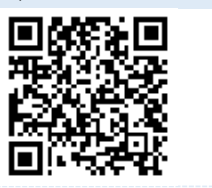

\section{(i)}

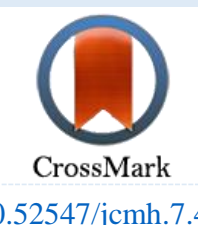

20.1001 .1 .24233552 .1399 .7 .4 .5 .3

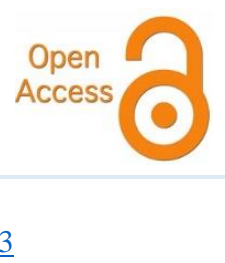

\section{A R T I C L E I N F O}

Keywords:

Curriculum,

multicultural curriculum, multicultural education

Received: 21 Jun 2020

Accepted: 19 Jan 2021

Available: 11 Mar 2021

\section{A B S T R A C T}

Background and Purpose: This study aims to explain the requirements of a multicultural curriculum based on the objectives of primary education and answers to this question that regarding the multicultural nature of Iranian society, which features should this curriculum contain and to what extent the current curriculum is based on these features.

Methods: This was a qualitative content analysis (inductive-deductive). The statistical population included authentic (valid) documents, including national curriculum, specialized texts, and theses related to multicultural curriculum and the educational package for primary school curriculum. Research sample included the national curriculum, related studies in multicultural countries, and the educational package for the course of social studies in the primary school. Purposive and criterion sampling was used by giving priority to the articles that were up to date and have a profound connection with the study subject. To collect the data, national and international sources in the area of multicultural education within the years of 2009 to 2020 were used. Finally, unrelated sources were excluded and 86 sources were analyzed. The social studies educational package was selected because it is more expected to contain multicultural components. Research data were collected through documentary research and were analyzed through a qualitative (descriptive-interpretive) method.

Results: In terms of the first research question, five components were extracted as the multicultural curriculum, including the observance of educational justice, acceptance of cultural pluralism, interest in peaceful coexistence, respect for divine religions and a combined approach in curriculum content. Based on the content analysis of these five themes, findings related to the second question showed low interest in multicultural curriculum components at all levels. However, the themes were not equally considered.

Conclusion: Low overlap between the book content and the course design guidelines, and the unbalanced, non-targeted, and inadequate distribution of multicultural curriculum components were among the results of this study. Based on the results, dominancy of exploration skill training approach, problem-solving, and critical thinking to present curriculum content are suggested.

* Corresponding author: Majid Ali Asgari, Associate Professor, Department of Curriculum Planning, Faculty of Psychology and Educational Sciences, Kharazmi University of Tehran, Iran.

E-mail: Aliasgari@khu.ac.ir

Tel: (+98) 2181584421

2476-5740/ (C) 2021 The Authors. This is an open access article under the CC BY-NC-ND license (https://creativecommons.org/licenses/by-nc-nd/4.0/). 


\section{Extended Abstract}

\section{Introduction}

The curriculum content is defined in the smallest and most effective element of the education system, i.e., the classroom where teachers and students coming from different cultural backgrounds, distinguished lived experiences, various cultural sources experience an everyday learning context(1-2). Combining individuals' cultural belief and their learning context would closely relate culture to learning (3). Thus, cultural fundamentals in the form of a multicultural curriculum should be considered. A multicultural curriculum is the rebuilding of the mono-national curriculum that requires proper contextualization to understand the necessity of a multicultural approach by authorities. Such bedding requires a dominant multicultural discourse (4). The combined approach is a step toward improving the multicultural curriculum through combining curriculum content and avoiding a single discipline (3). Such planning has profoundly influenced the procedure of features development and thus many countries made their educational system committed to the improvement of knowledge and multicultural skills in their students (4). Developing ethno cultural literacy and teaching multicultural skills have created cultural understanding and brought peace and social cohesion, leading to the sustainable development of countries (5).

In addition to emphasizing the necessity of multicultural themes in the curriculum, literature also confirms the gap in the current education system (25-29). As prior studies verified the existence of a separate subject-oriented curriculum in the primary education and with respect to the lack of a conceptual model underlying multicultural curriculum framework, the research gaps are demonstrated $(9,14)$. In this regard, the purpose of the present research is to explain the requirements of a multicultural curriculum based on primary education objectives.

\section{Method}

This is an applied study in terms of purpose and qualitative descriptive research (deductive-inductive) in terms of method. The first research question investigated multicultural curriculum components.
The research population included two parts: the first part was the national curriculum, and the second part included specialized texts, valid papers, and educational websites of other countries having multicultural experiences with combined approach. Research sample included national curriculum and related literature selected through purposive sampling method. Categorized tables collected research data through documentary research. Data were analyzed by qualitative content analysis (deductive research approach). The second research question studied the overlap between the current primary education curriculum and multicultural curriculum. The statistical research population included educational package (curriculum guideline, course book, and teacher book) compiled by the organization for educational research and planning in 2012. The educational package of the social studies course in primary school was used as the research sample. This course was considered as it embraces higher multicultural component expectations comparing other courses (29). Purposive and criterion sampling was done. Research samples were background and related texts, and analysis unit was multicultural related concepts. Data were collected using a conceptual matrix table of deductive content analysis featured with a literature review based on the multicultural curriculum features. Data were collected by documentary review using a researchermade content analysis list and analyzed by a qualitative content analysis (deductive research approach). The results accuracy was assessed by a reliability criterion (33) in qualitative studies.

\section{Results}

In the first step, the multicultural curriculum features were explained in the framework of primary education principles using the inductive qualitative content analysis method. The process contains free coding, classification, and sub-classification and meaning extraction (30). Categories of educational justice observance include equal distribution of scholarly sources and services for all individuals regardless of attributive features and attention to the special requirements of students with different needs (needs) (4-5). Categories of cultural pluralism acceptance include familiarity with the evolution of cultures, 


\section{Quarterly Journal of}

culture recognition and promotion, strengthening the power of cultures, as well as familiarity with ethnic cultural literature (2). Peaceful coexistence categories include improved intercultural relations, openmindedness, and admitting unity despite plurality (910). The features of respect for divine religions in the multicultural curriculum are subcategorized as follows: familiarity with monotheistic religions' teachings and respect for the inherent dignity of human beings (39). The categories of multicultural curriculum's combined approach embrace applying justice-based pedagogy through flexible curriculum content, varied teaching, assessment methods, and learning contexts (11).

In the second research question, five themes from the first research question were deductively analyzed in the social studies educational package for the four primary education levels through content analysis (30). In educational justice observance, the analysis operations included embracing ethnic characteristics in providing educational facilities, and attention to the needs of the students suffering from social problems and/or cultural and economic poverty (36). Analyzing cultural pluralism acceptance includes awareness of cultural histories and utilizing ethnic and cultural achievements (37). The peaceful coexistence analysis resulted in creating intercultural respect, intercultural dialogue context, and enhanced individual identity to strengthen the national identity (38). In respect for divine religions, the analysis resulted in respect for values and norms of religions, acceptance of religious minorities, and instructing desired human relations (39). The analysis for the combined approach of the multicultural curriculum provides caring for cultural, geographical, and historical requirements and applying combined approach-based teaching methods (40). According to the quality and quantity of open coding, the scholar found that multicultural curriculum components were relatively ignored in all levels; however, the themes were differently processed.

\section{Conclusion}

Multicultural education is an emergency need for multicultural communities that requires a multicultural curriculum. Studies indicated the poor overlap between social studies educational package content in Iran with the aforementioned multicultural components (25-29).

In the first research question, educational justice observance highlights that all learners deserve equal educational opportunities at school regardless of their nationality, class, religion, and gender (21). Cultural pluralism acceptance tries to highly signify the educational needs of societies made up of different cultures (37). Peaceful coexistence seeks to prepare individuals for peaceful coexistence in a multicultural community (38). The respect for divine religions would extend students' attitudes in religious recognition and appropriate conduct against different religious beliefs (39). The combined approach intends to change and adjust the education process to affirm the multicultural value (40).

In the second research question, providing opportunities to identify ethnic, cultural literature through art and literature enhance the powers of cultures, and cultural recognition and development were relatively considered and related to the acceptance of cultural pluralism. The other remaining categories (educational justice observance, peaceful coexistence, respect for divine religions, and a combined curriculum approach) (25-29) were almost equally ignored in the book content. It is evident that in the age of information explosion, the inclusion of all the considered concepts of a course in a curriculum is a misplaced expectation; thus, inquirybased instruction, problem-solving, and critical thinking approaches were proposed to remove curriculum content limitations (19).

The research limitations include problems in accessing the curriculum sources of countries with multicultural experience and lack of high-quality national studies. Curriculum planning based on a multicultural framework for public education, explaining a multicultural approach for influential academics, and instructing multicultural teaching and assessment methods to the teachers are proposed as the research implications. 


\section{Quarterly Journal of Child Mental Health}

Vol. 7, No. 4, Winter 2021

\section{Ethical Considerations}

Compliance with ethical guidelines: This article was extracted from the Ph.D. dissertation of the first author, which was approved in the field of Curriculum Planning at Kharazmi University of Tehran, with the number 18843 and successfully defended on 07 DEC 2020.

Funding: This study was conducted without the financial support of any public or private institution or organization.
Authors' contribution: The first author who conducted the research is the senior author, the second and third authors are the supervisors and the forth and fifth ones are the advisors.

Conflict of interest: No conflict of interest was reported by scholars.

Acknowledgments: All the individuals and institutes who made contribution in conducting this study as well as the supervisors and advisors are highly appreciated. 


\section{ضرورتهاى برنامه درسى جندفرهنغى در دوره ابتدايى: تبيين ويزگى ها بر اساس روى آورد تلفيق}

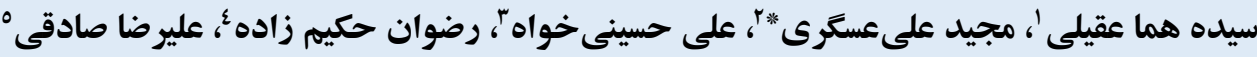

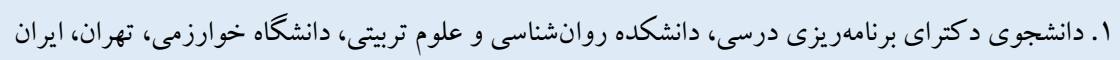

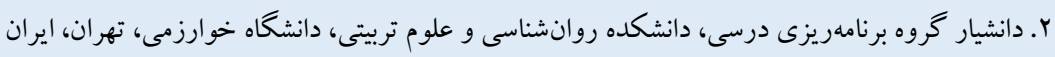

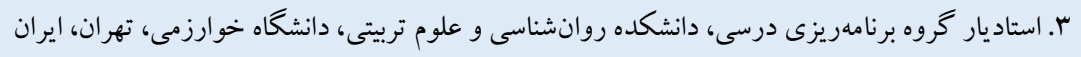

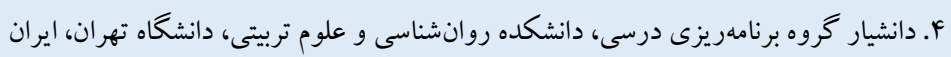

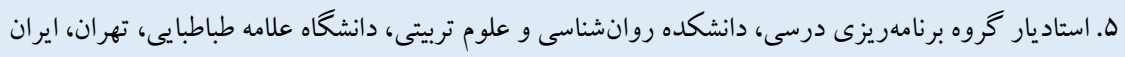

\section{جك}

زمينه و هدف: هدف اين بثوهش، تبين ضرورت هاى برنامه درسى جند فرهنگى بر اساس اهداف تعليم و تربيت آموزش ابتدايى بوده و

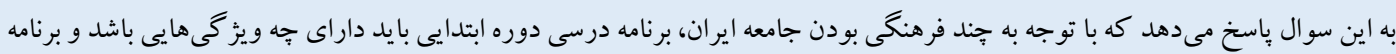
درسى موجود تا جه اندازه مبتى بر اين ويثز گهى ها است.

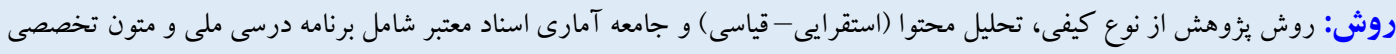

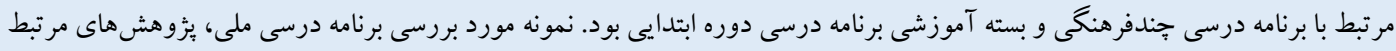

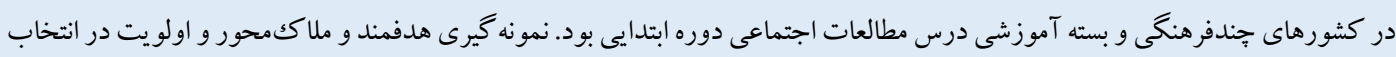

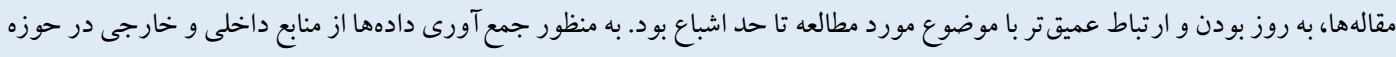

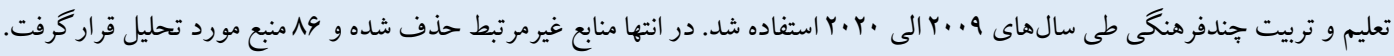

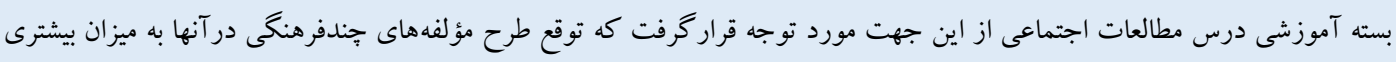
وجود دارد. براى گردآورى دادهها از شيوه بررسى اسنادى و براى تحليل دادها از روش كيفى (توصيفى - تفسيرى) استفاده شد. يافتها: در يرسش اول ينج مؤلفه شامل رعايت عدالت آموزشى و تربيتى، يذيرش تكثر فرهنگى، توجه به همزيستى مسالمت آميز، احترام

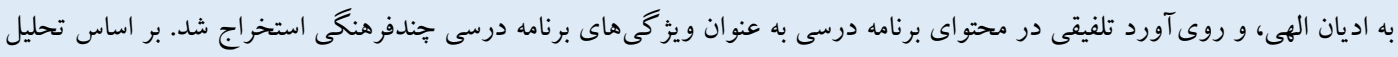

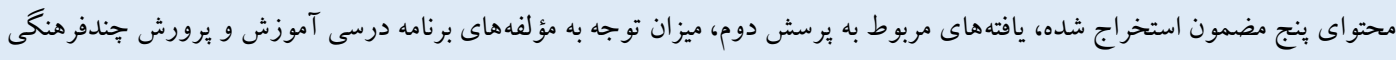

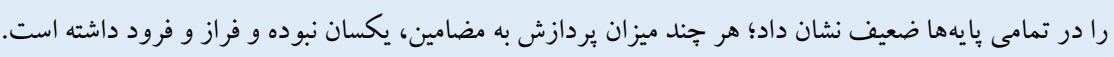
نتيجه كيرى: هميوشانى ضعيف محتواى كتاب با راهنماى درسى و توزيع نامتوازن، غيرهدفمند، و ناكافى مؤلفههاى برنامه درسى

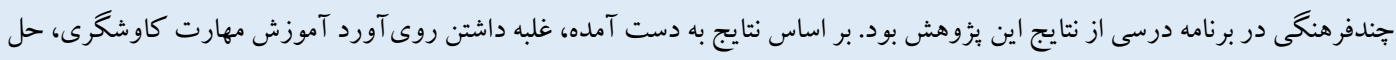
مسئله و تفكر انتقادى جهت ارائه محتواى برنامه درسى بيشنهاد مى بـ برود.
مشخصات مقاله

كليدوازهها:

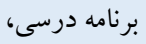

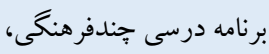
آموزش تجند فرهنگى
دريافت شده: 1 • 99/F

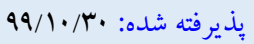
منتشر شده:

* نويسنده مسئول: مجيد على عسكرى، دانشيار گروه برنامهريزى درسى، دانشكده روانشناسى و علوم تربيتى، دانشگاه خوارزمى، تهران، ايران.

Aliasgari@khu.ac.ir رايانامه

تلفن: 


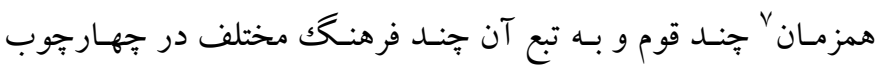

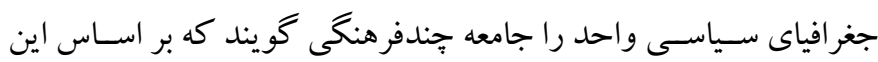

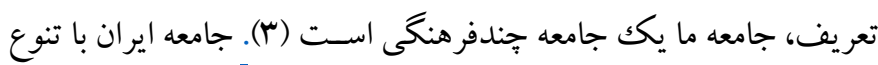
اقليم و اختلاط نزادى و قومى، شـرايط خاصى را ييش روى سياستمداران

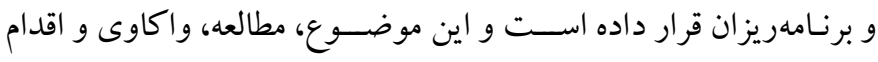
مناسـب را جهت همخر ايى و انسـام اجتماعى مى طلبد. در اين راسـتا از

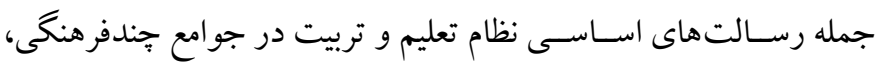

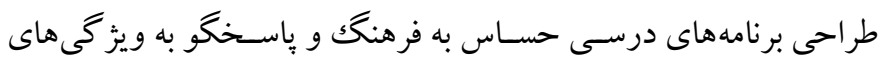

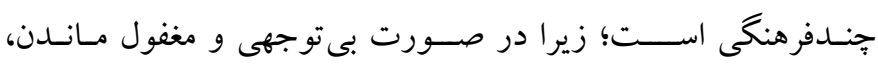

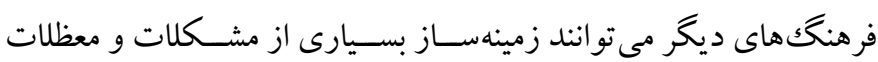

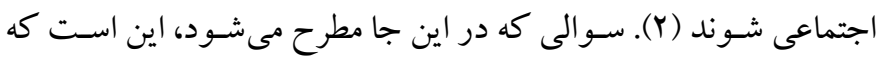

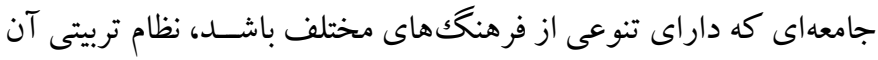

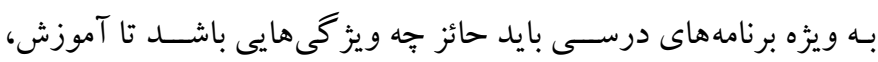

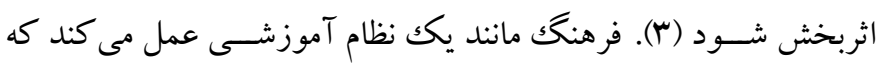

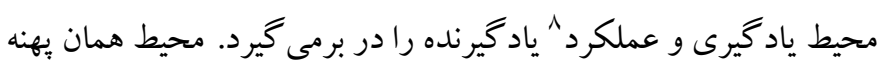

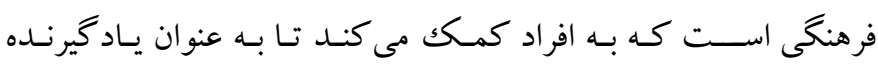

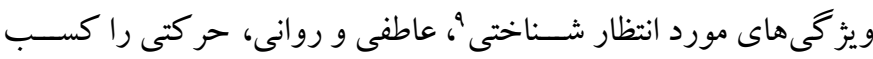

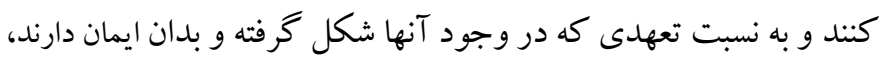

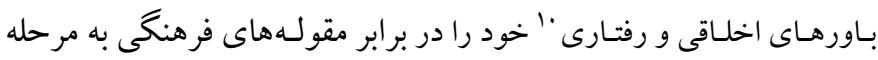

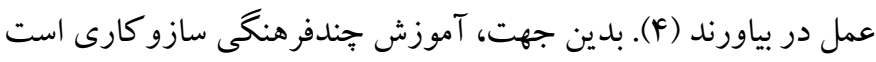

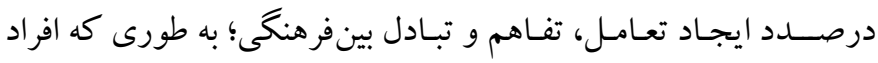

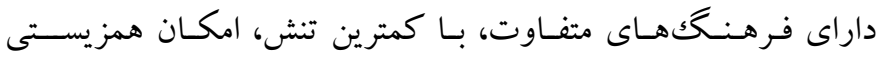
مسالمت آميز بيدا كنند (ه).

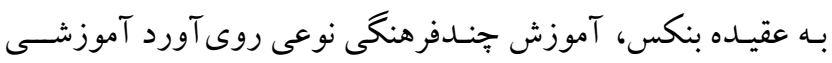

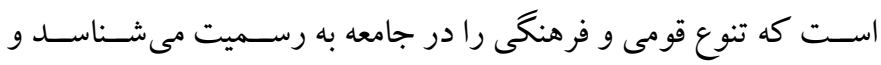

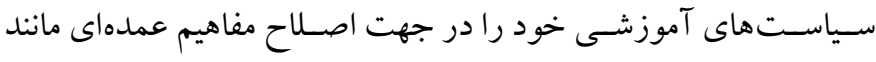

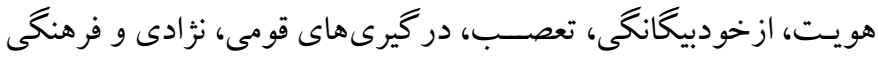

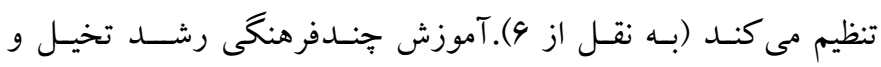

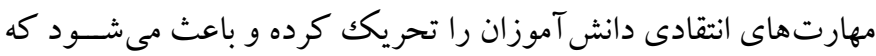

6. Cultural pluralism

7. Concurrent

8. Performance

9. Cognitive

10. Behavioral
مقدمه

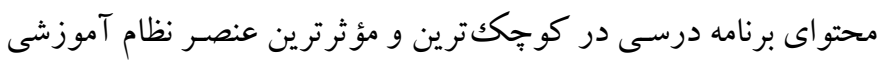

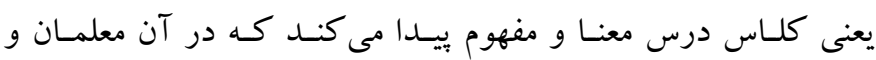

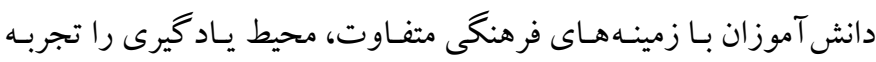

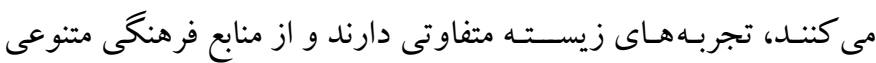

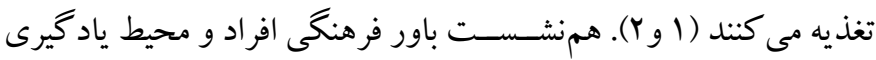

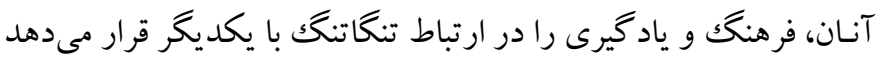

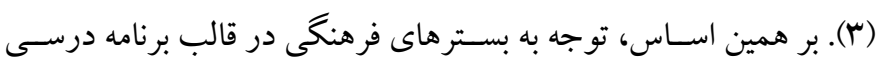
جند فرهنگ四 مورد توجه قرار مى گيرد.

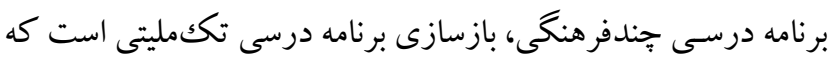

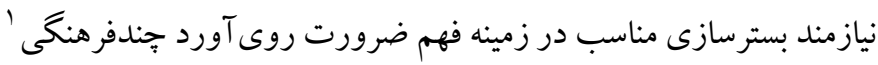
از سـوى صـاحب نظر ان اسـت. فراهم شدن جنين زمينهاى نيازمند كفتمان

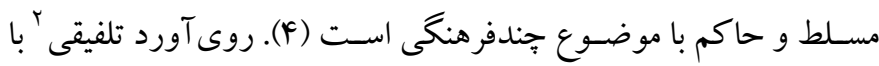

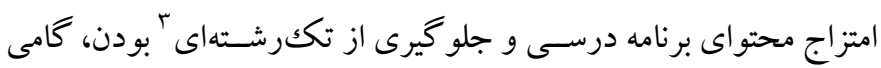

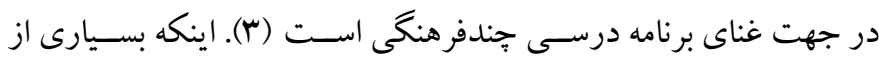

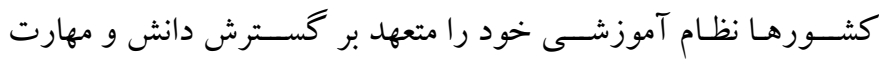

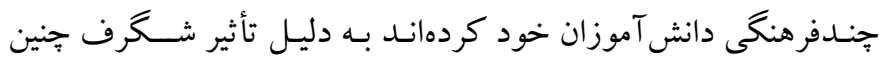

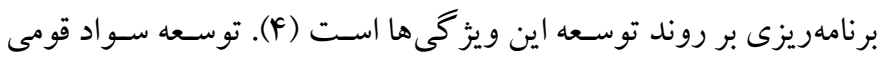

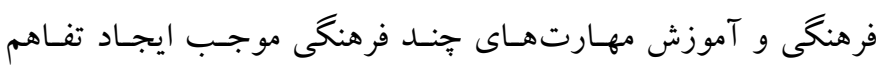

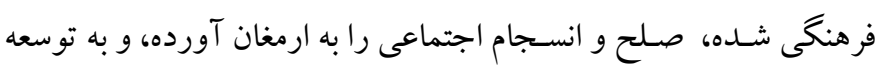

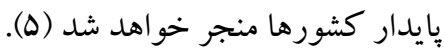

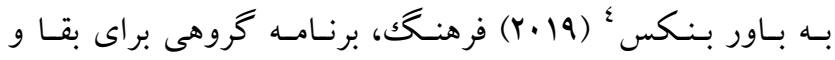

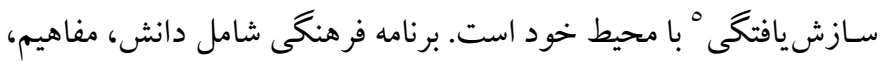

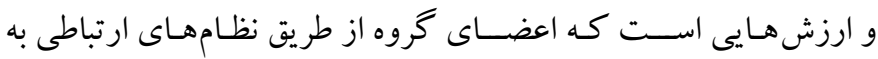

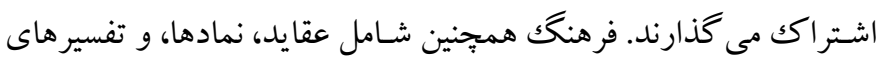

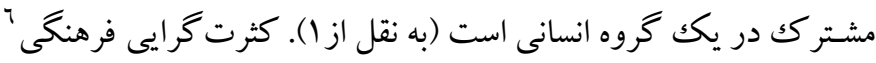

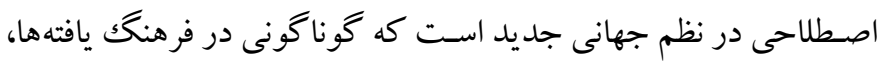
نظام هاى عقيدتى و ارزش يافتها را به رسـميت مى شــاسد (Y). و واقعيات،

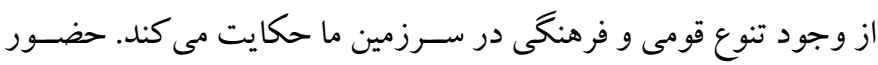

1. Multicultural approach

2. Integrated approach

3. Single discipline

4. Banks

5. Compromise 
نز ادهـاى جـامعه را به وجود آورده و وحدتبخشـى فرهنكى و وحدت

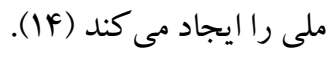

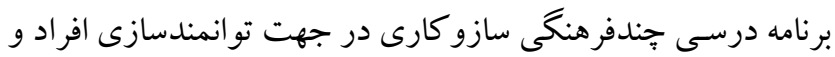

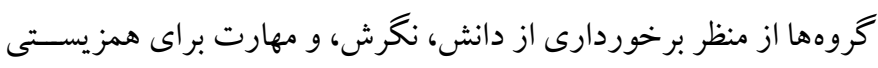

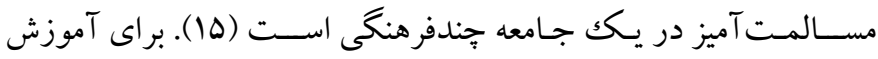

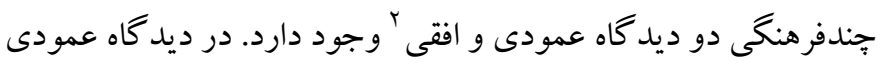

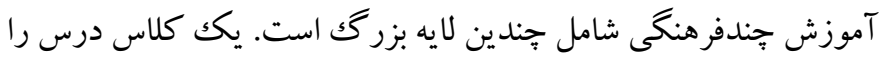

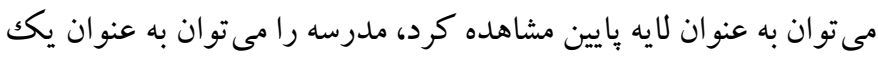

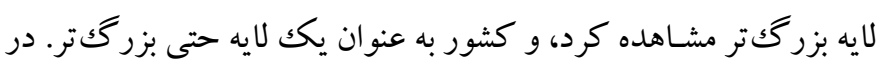
ديدگاه افقى آموزش جندفرهنگى مى تواند يكك متغير واحد يا متغيرهاى

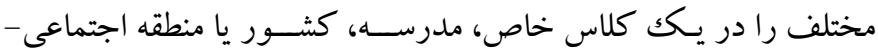

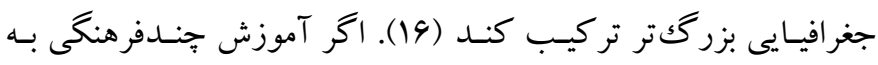

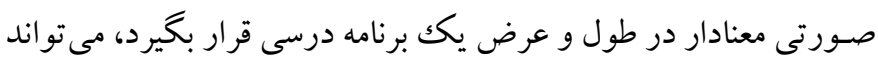

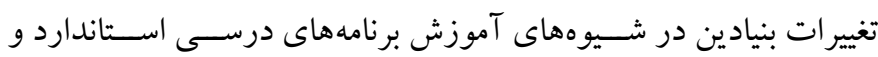
غير اسـتـانـدارد ايجـاد كند (IV). برنامههاى درسسى ســنتى، مفاهيم و موضـوعات مجزا از هم و تصــنعى را به دانش آموزان منتقل مى كنند كه موجب احسـاس بىربطى، بيهود گى و سردر گمى آنان مى شود. با آشكار

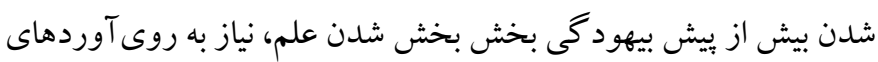

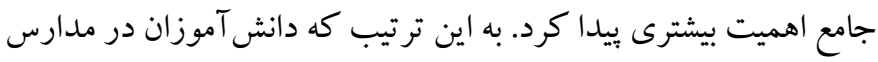

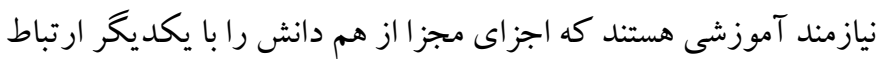

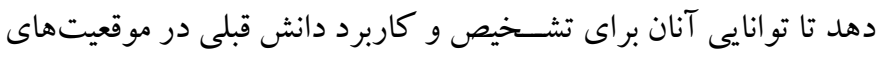

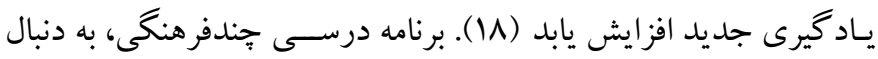

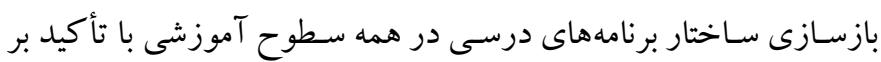

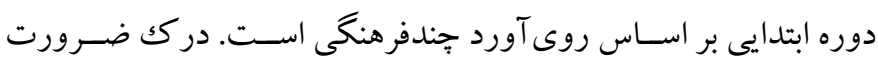

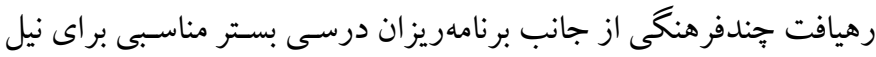

$$
\text { اين هدف محسوب مى شود. }
$$

آموزش و يرورش بر هدي تسـهيل در نائل شـدن به اهداف و آرمانهاى

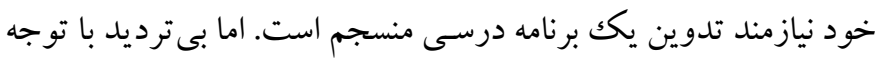

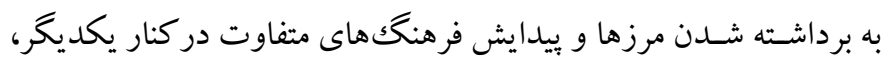

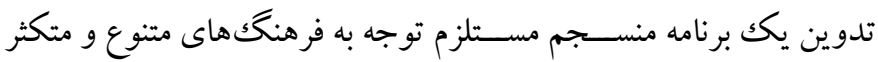
موجود در جـامعـه اسـت (9 1). واقعيـت اين اســت كه در جامعه امروز
آنها فرهنگكهـاى ديخر جوامع را به وســـله هنجارها و اســانداردهاى خودشـان قضـاوت كرده و قابل يذيرش بداند (V). لزوم اسـتقرار برنامه

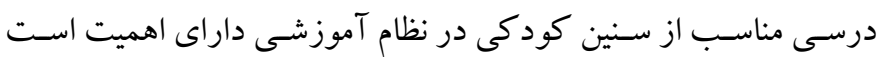

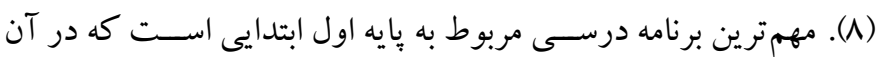

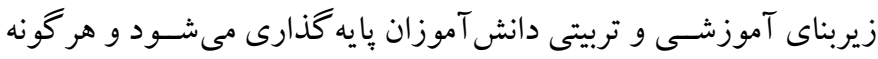

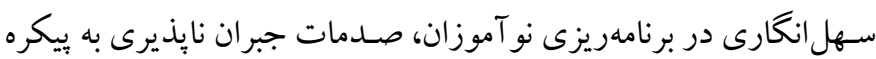

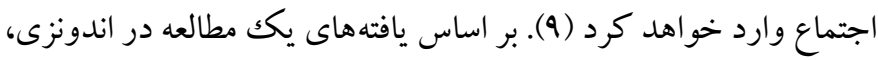

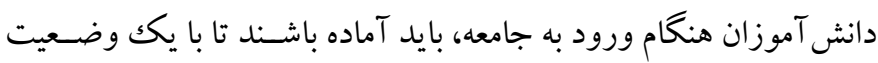
كثرت گرا روبرو شـوند. هنگام تحصسيل در مدرسهه، به دانش آموزان بايد

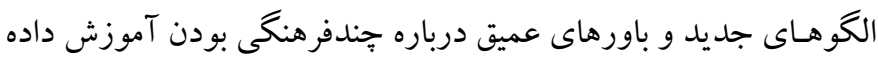

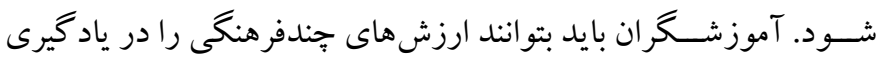

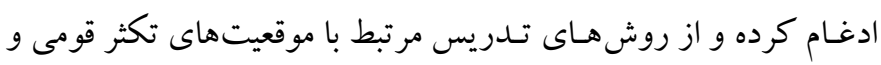

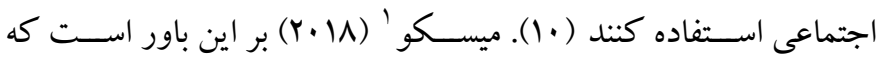

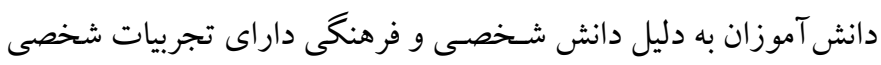

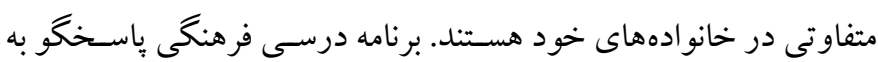
طور مفهومى به دنبال ايجاد ارتباط بين خانه و مدرسـه اسـت (11). نتايج

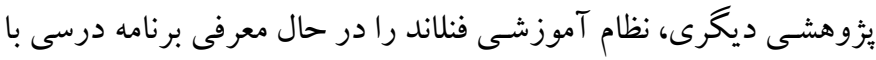

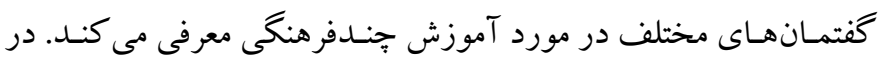

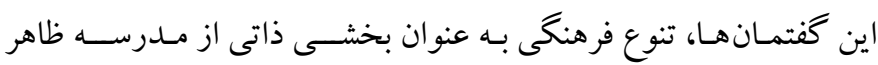

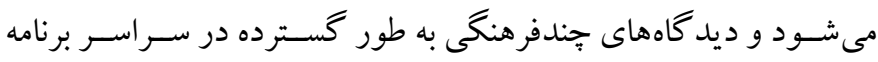

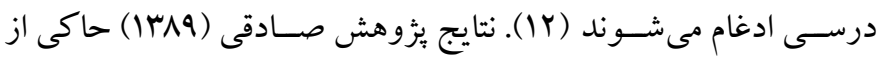

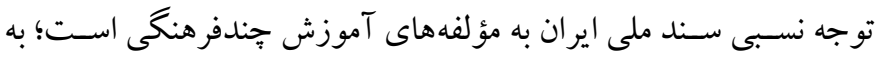

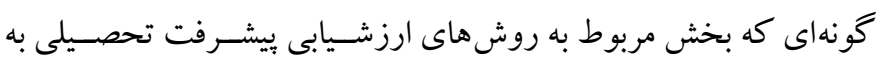

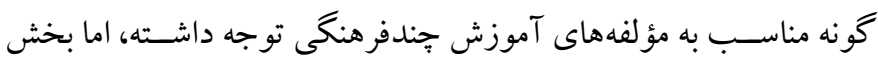

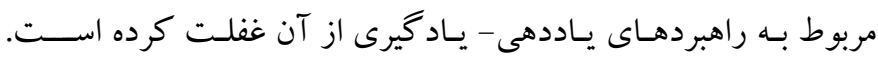

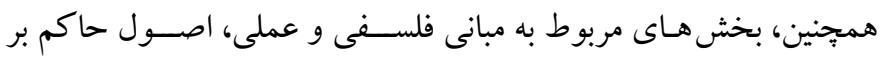

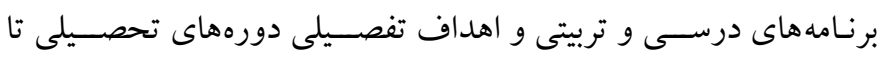

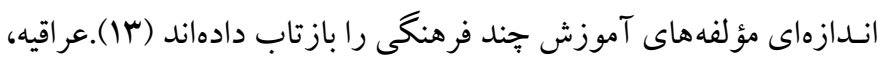

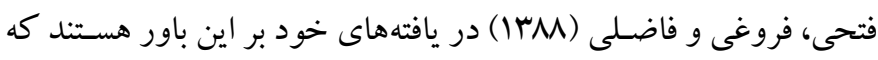

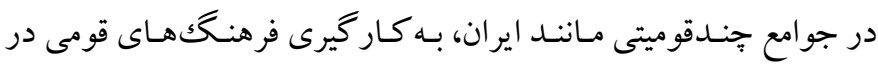

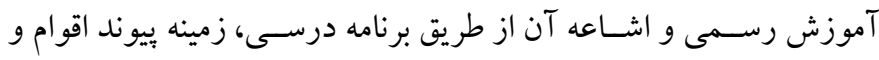


در آموزش و يرورش ايران بـه عنوان يكك حوزه مغفول و غايب روشــن

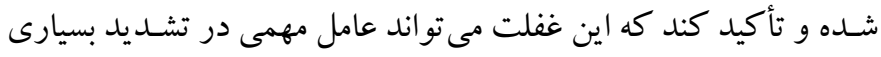

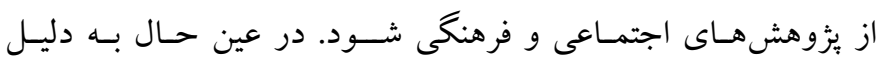

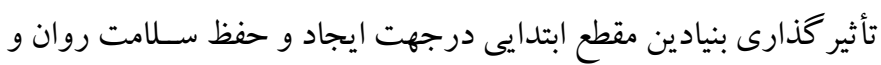

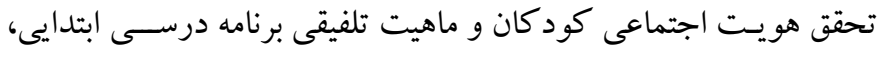

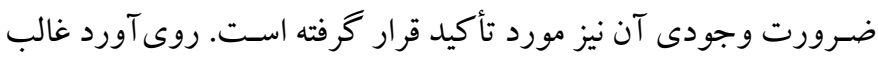

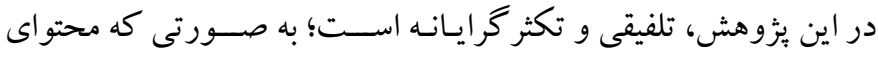

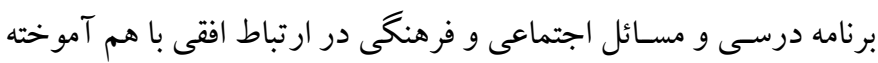

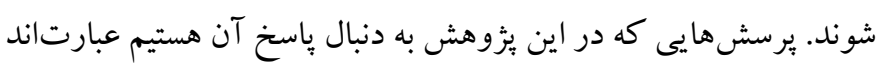

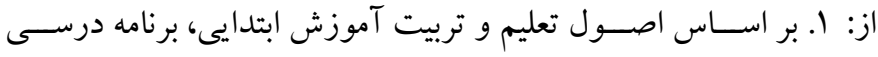

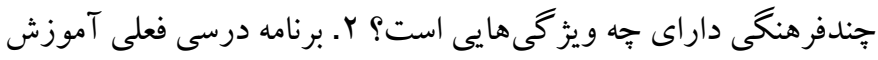

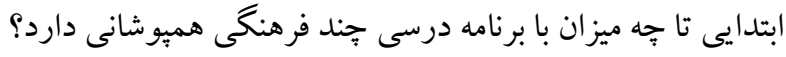

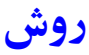

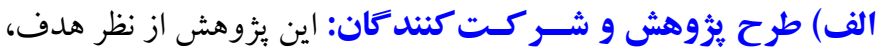

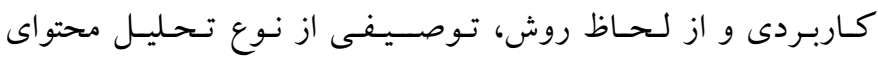
كيفى ((استقر ا-قياس) اسـت. سـه مرحله اسـاسى در فرايند انجام تحليل

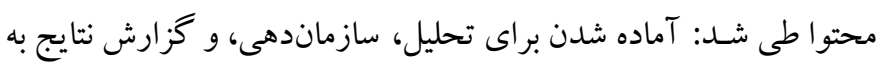

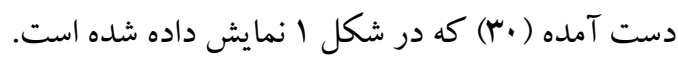

مجموعهاى از فرهنك ها در كنار هم قرار گرفتهاند كه غالباً هميوشــانى

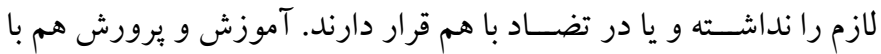

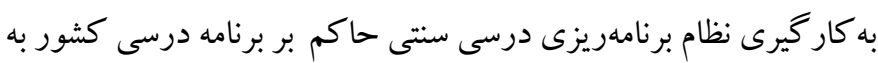

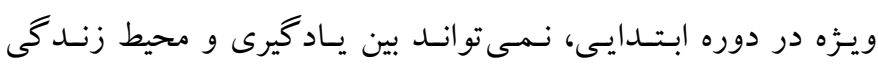

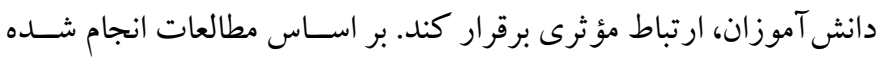

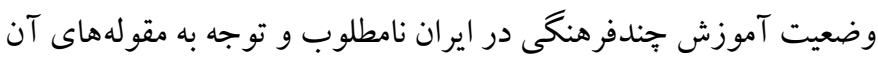

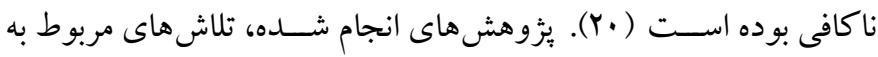

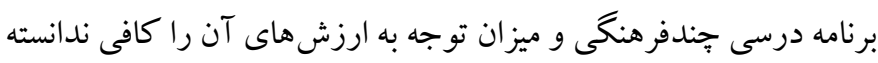

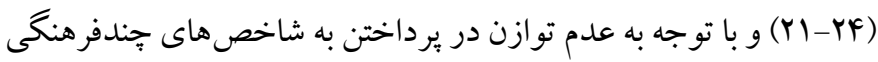

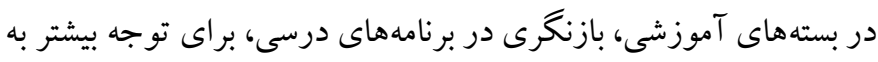

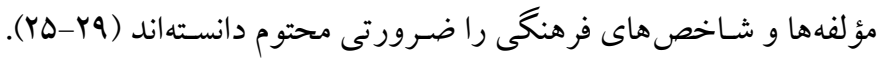

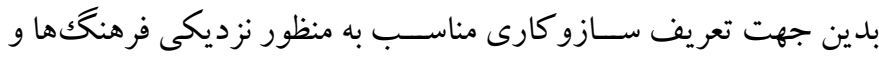
ايجاد تفاهم و تعامل ميان آنها در جهت همز يستى مسالمت آميز از دوران منان

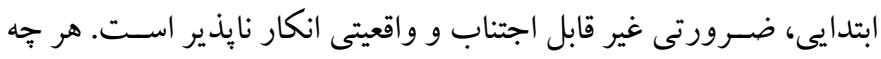

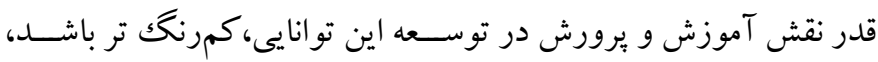
تعاملات افر ادى كه در اين گســتره جغر افيايى ملزم به داشــتن ارتباطات

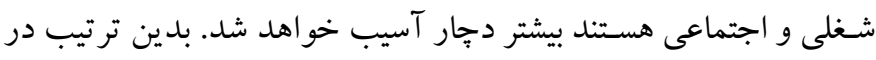

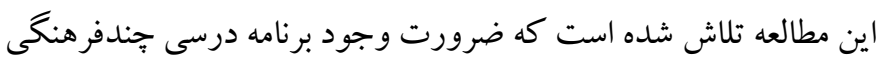

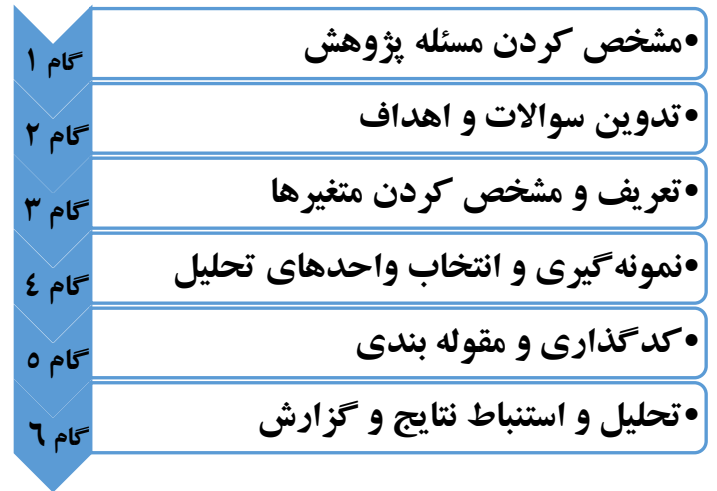

شكل ا: مراحل تحليل محتواى كيفى (•r)

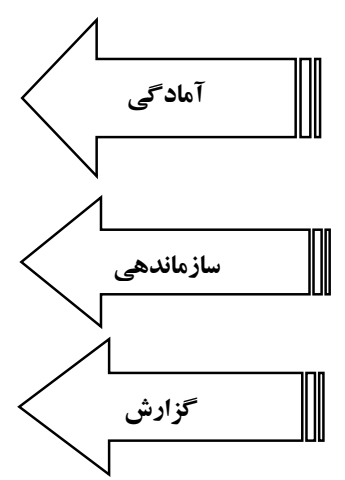

اســتفاده قرار مى گيرد كه هدف از ييش تعيين شــدهاى براى اين تحليل وجود دارد وكلمات، جملات، يا عبارات مشسخصى در متون جستوجو مىشــوند. تمايز بين اين دو روش، بيشــتر به نحوه شــكل گيرى مقولات
اســتقر ادر روش تحليـل محتو اي كيفى به عميق شـــدن در دادهها و فرصـت دادن به ظهور بينشها؟ و افتهاى تازه و طبقات اسـتقر ايى جديد كُفته مىشـود؛ ولى تحليل محتواى قياسـى، زمانى در يك بزّوهش مورد 


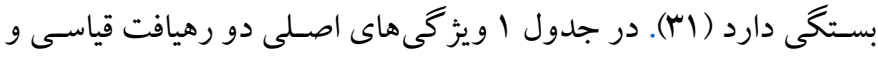
استقر ايى در تحليل محتواى كيفى، نشان داده شده است:

جدول 1: دو رهيافت اصلى در تحليل محتواى كيفى(Tr)

\begin{tabular}{|c|c|c|c|}
\hline منبع كدها و يا مقولات & شروع بزوهش & تعريف كدها و مقولات & انواع تحليل محتواى كيفى \\
\hline استخراج كد از دادهها & 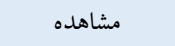 & در فرايند تحليل دادهها & تحليل محتواى استقرايى \\
\hline استخراج كد از نظريههاى يُزوهشى & نظريه & تعريف كدها يِيش از تحليل و در خلال آن & تحليل محتواى قياسى \\
\hline
\end{tabular}

ب) ابزار بثزوهش: ابزار گردهدآورى دادهها براى برسـش نخسـت، جدول

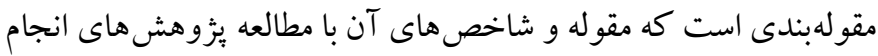

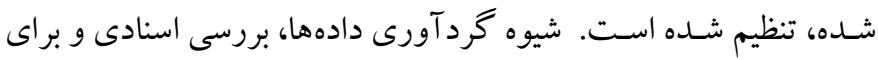
تجزيه و تحليل دادهها از تحليل محتواى كيفى (استقر ايى) اسـتفاده شـده

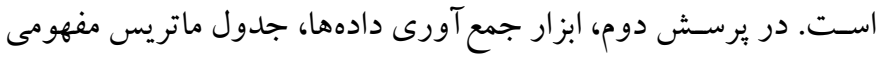
تحليل محتواى قياسى بوده اسـت كه مقوله و شـاخص هاى آن با مطالعه

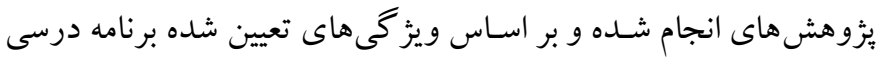

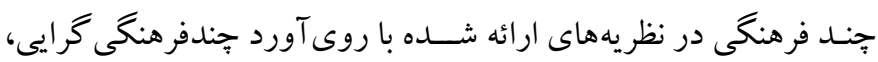

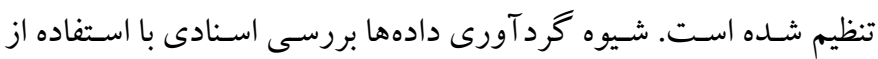
ســـــــهـ تحليل محتو اى محقق ســاخته و براى تجزيه و تحليل دادهها از تحليل محتواى كيفى (قياسى) استفاده شده است (آب).

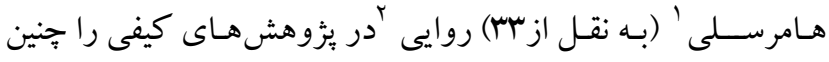

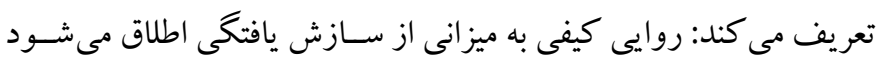

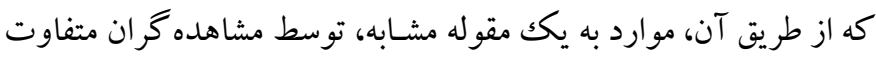
يا يكك مشـاهده

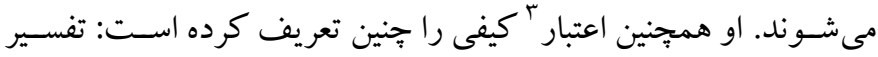

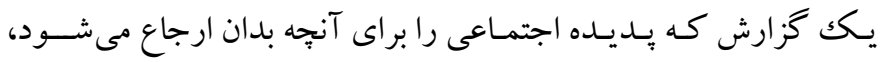

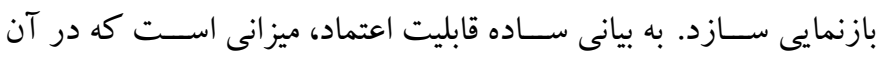

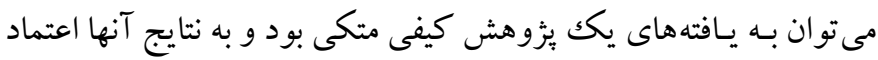

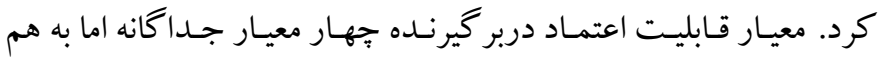

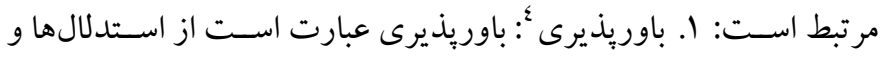

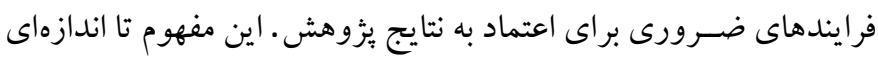

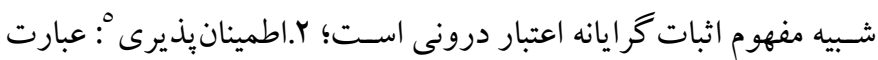

4. Crediability

5. Dependability
در ياسـخ به يرسـش اول، مؤلفه هاى برنامه درسى جندفرهنكى مورد بررسى قرار كرفت. جامعه يُزوهشى شـامل دو بخش بوده اسـت: بخش يكم اســـــاد معتبر شـــامـل برنـامه درســى ملى ايران؛ و بخش دوم متون تخصصى، مقالات و مجلات داخلى ايران و خارج از ايران درباره آموزش و يرورش كشــورهـاى جنــدفرهنگى. روش نمونسه كيرى، هـدفمنـد و

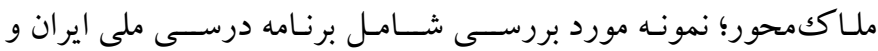
يزٔوهش هاى مرتبط؛ زمينه، متن برنامه درسـى ملى و بزوهش ها؛ و واحد

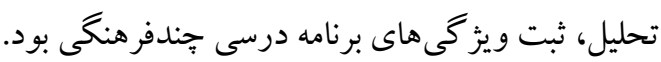
در باسـخ به يرسش دوم، ميزان هميوشانى برنامه درسى فعلى آموزش ابتدايى با برنامه درسـى جندفرهنكى مورد بررسـى گر فته اسـت. جامعه آمارى اين ئزوهش شـامل بسـته درسـى (راهنماى برنامه درسـى، كتاب درســى، و راهنمـاى معلم دوره ابتـايى) بوده اســت كـه توســــ دفتر برنامهريزى و تأليف كتابهاى درسى در سال اهبا تأليف و جاب شده اسـت. نمونه مورد بررسـى در اين يثوهش شـامل بسـته آموزشسى درس مطالعات اجتماعى دوره ابتدايى اسـت. بسـته آموزشى مطالعات اجتماعى از اين جهـت مورد توجـه قرار گرفت كه نســبت به ديخر موضــوعات درســى، توقع طرح مؤلفـههـاى جنـدفرهنگى در آن بيشــتر وجود دارد. نمونه گيرى هدفمند و ملاككمحور و در جهت سوال يزوهش بوده است.

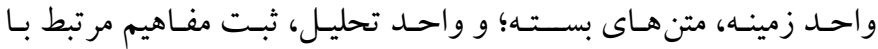
جنـدفرهنكى بود. كليدوازههاى به كار برده شـــده در جســتجو شــامل وازههاى جندفرهنكى، برنامهى درسى جندفرهنگى و تلفيق برنامه درسى

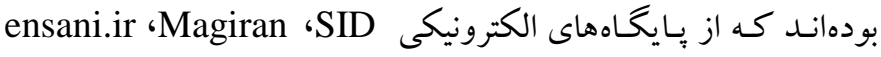
Elsevier ‘ProQuest ،Eric ‘IranDoc ،Normagas ‘Sivilica ،

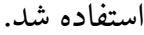

1. Hummersley

2. Validity

3. Credit 
براى يـك جمعيـت متفـاوت بـه كار رود. بدين ترتيب، اعتماديذيرى هر جهار معيار ياد شـــه را در بر مى گيرد و به عنوان ميزانى تعريف مى شــود

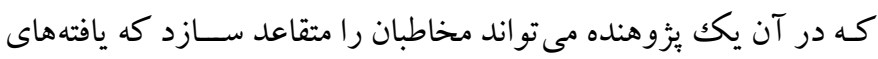

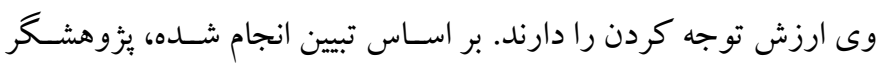

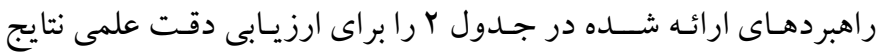

$$
\text { يثزوهش به كار برده است. }
$$

اسـت از توانيى شـناسـايى جايى كه دادههاى يكك مطالعه معين از آن جا

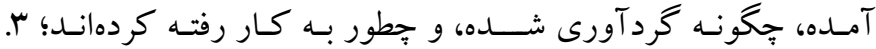

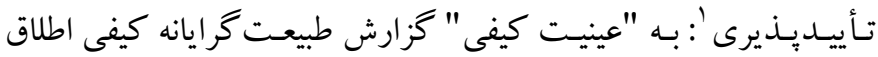
مى شود. در اين زمينه يُزوهنده بايد نشان دهد كه يافتهاى هاى آن عملاً و و اقعاً

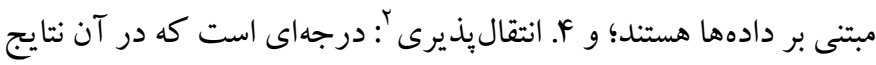
يكك مطالعه كيفى مى تواند به يكك محيط متفاوت ديخر نيز منتقل شـده و

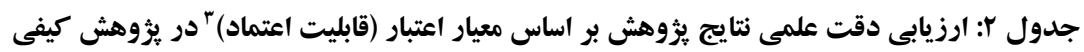

\begin{tabular}{|c|c|c|c|c|}
\hline راهبردهاى به كار كرفته شده در ثئوهش توسط يزوهشكر & تعريف معيار & معادل كمى & معيارهاى ارزيابى & رديف \\
\hline 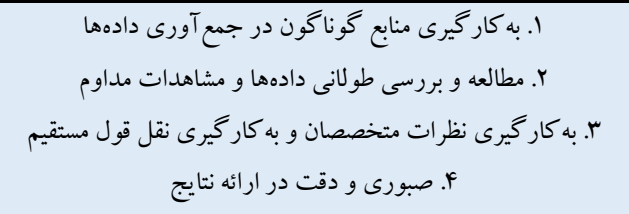 & 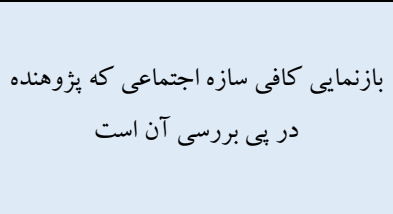 & $\begin{array}{l}\frac{2}{y j} \\
\frac{\hat{y}}{3}\end{array}$ & 3.ं. & 1 \\
\hline 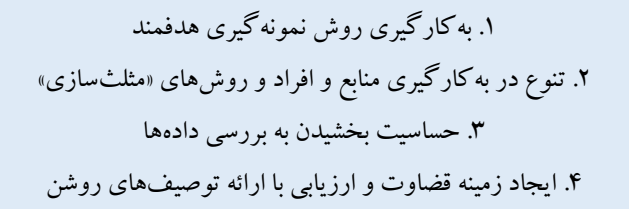 & يزوهش بايد در تفسير و تحليل دادهها & 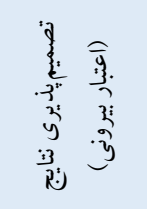 & $\begin{array}{l}3 \\
3 \\
3 \\
3 \\
3 \\
3\end{array}$ & $r$ \\
\hline 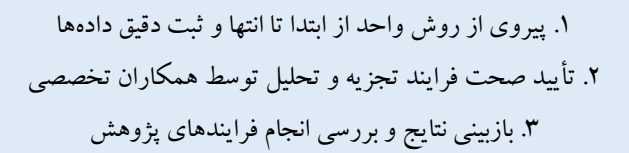 & اين گويه به ثبات نتايج در طول زمان & 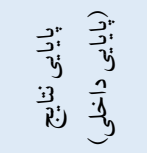 & 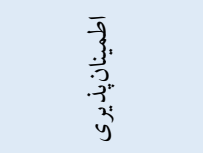 & r \\
\hline 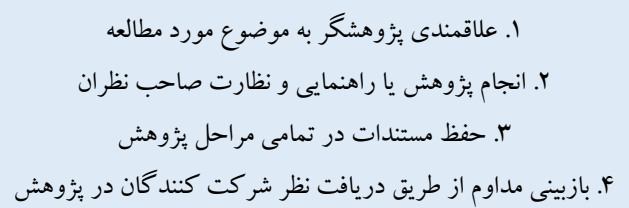 & ميزان تأييد ويزَّى هاى دادههاى مورد & 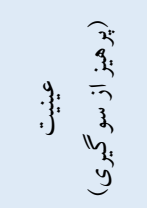 & 年, & F \\
\hline
\end{tabular}

متغيرهـا (·ץ): مفاهيمى كه اين بزوهش به بررسـى آنها در متن برداخته

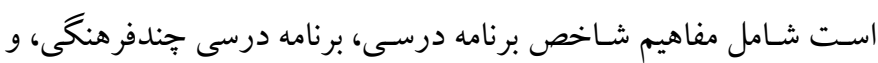

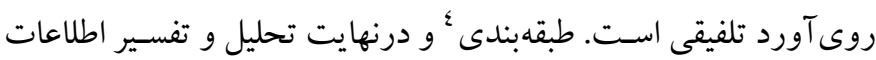

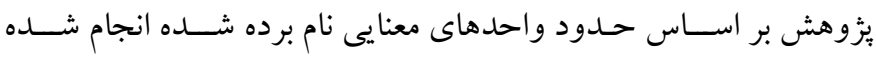

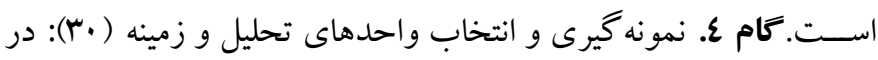

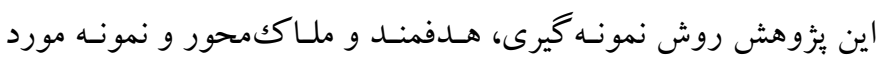
بررسـى برنـامـه درسسى ملى و يُزوهش هاى مر تبط در داخل و خارج از

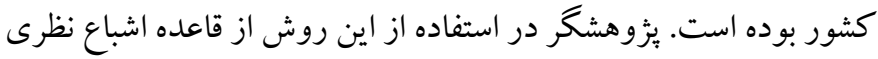

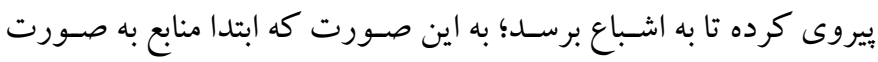

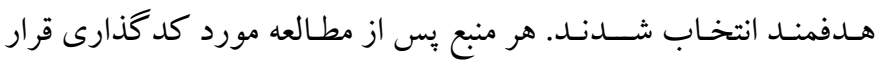

ج) روش اجرا: كامهاى اجرايى برسش يكم

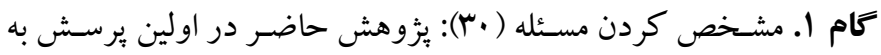

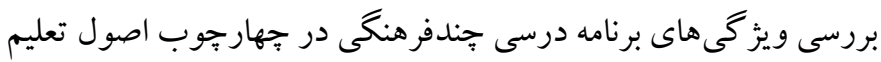

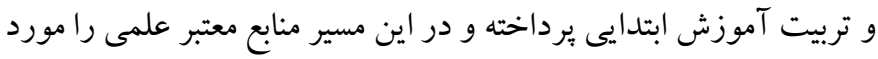

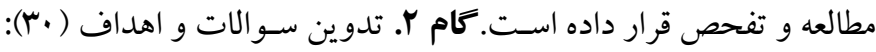

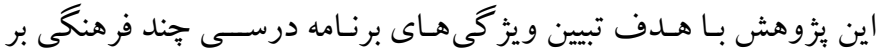

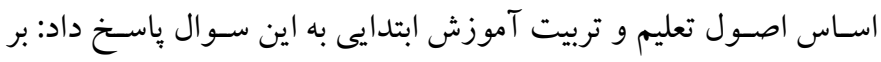

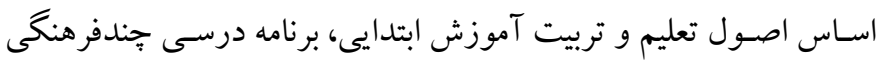

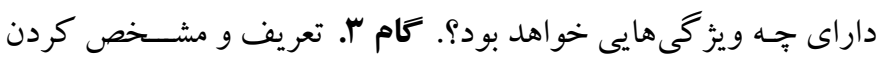


كـد ايجـاد شـــــ كـه پِ از حـذف و ادغـامهاى انجام شــــه در مراحل

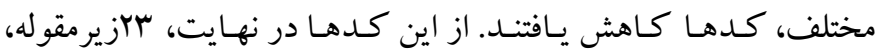

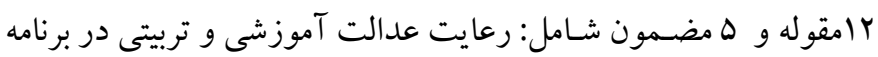

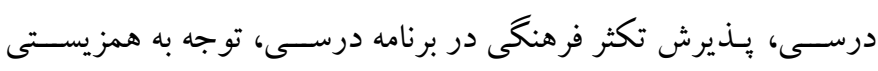

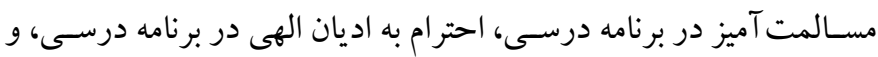

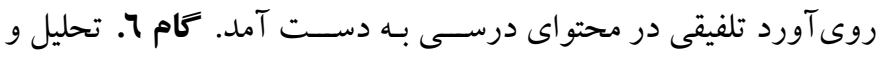

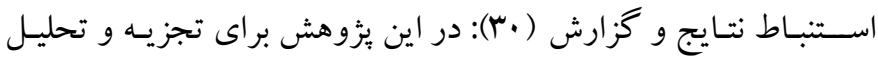

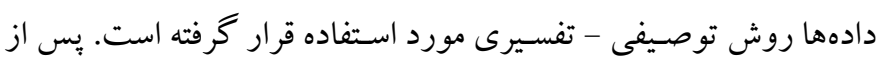

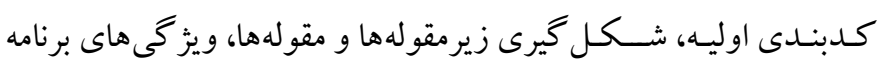

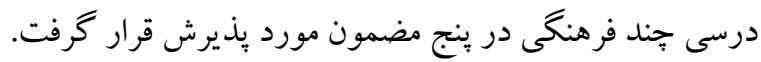
كامهاى اجرايع برسش دوم:

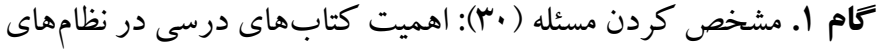

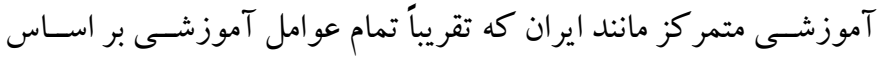

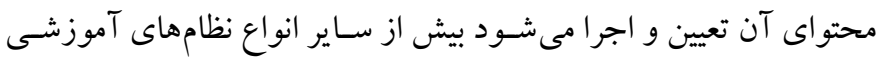

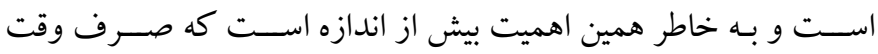
نيروهاى متخصـص در ارزشـيابى و تحليل كتابهاى درسـى مى تواند راهخشـاى حل بسيارى از مشكلات جارى آموزش باشد (MF). در حوزه برنامهريزى و سياسـت كذارى آموزشى، به تدوين دقيق برنامه درسى نياز

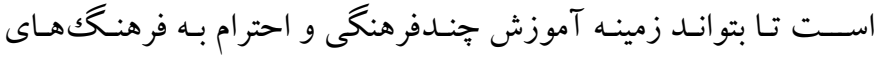

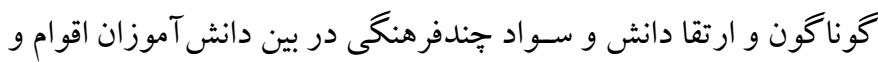

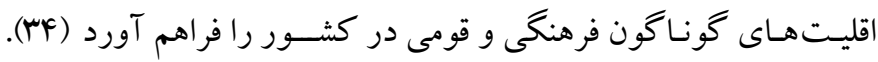

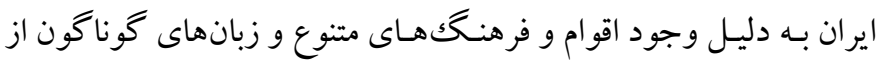

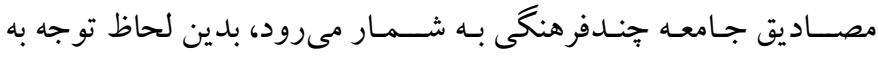

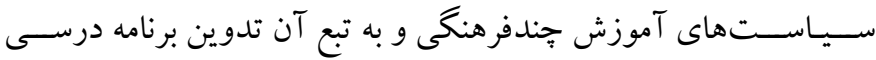

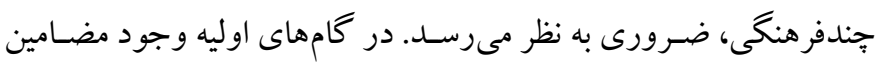

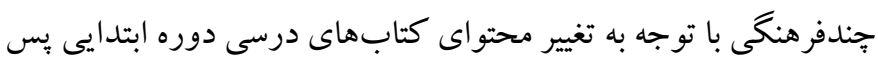
از اجراى نظام آموزشى 9-r-r مى تواند زمينهسـاز برداختن به ضـرورت

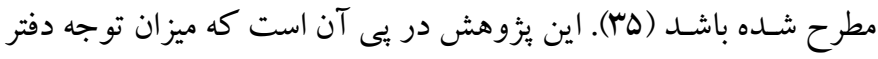

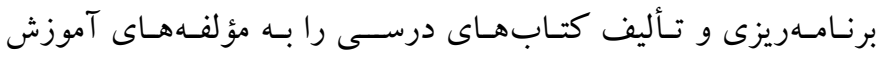

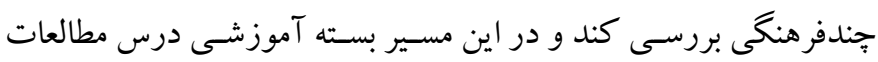

كرفت و بعد از آن منبع ديخرى انتخاب شده و مورد بررسى قرار گرفت.

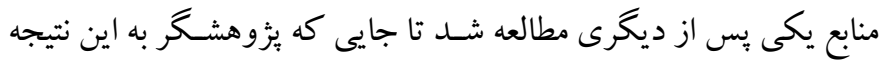
رسيد كه مطالعه به حد اشباع مقولهاى و نظرى رسيده است. از اين طريق

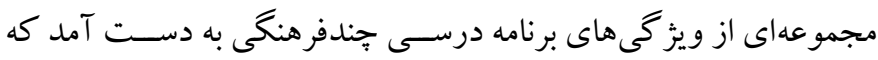

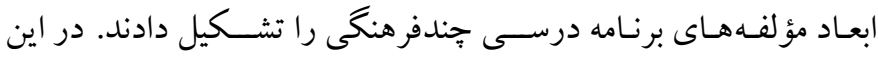
يُزوهش واحد زمينه، متن برنامه درسسى ملى و ويزوهش ها و واحد تحليل،

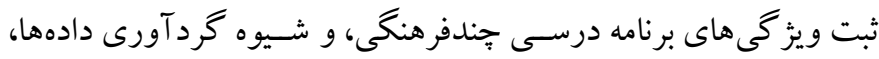

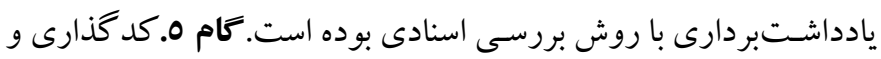
مقولهبندى (·r): سـازماندهى دادههاى كيفى حاصـل روسل از مطالعات انجام

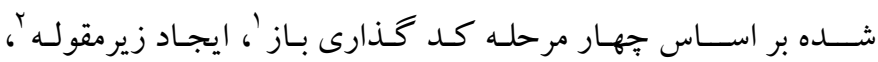

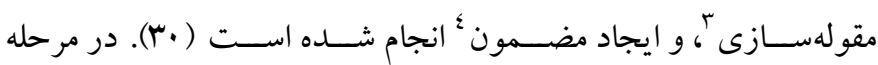

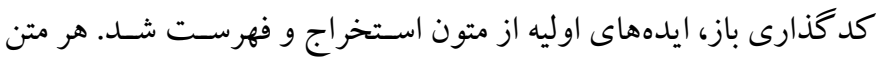

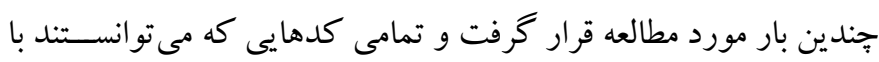

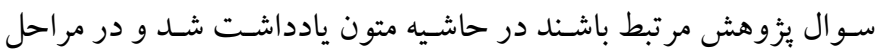

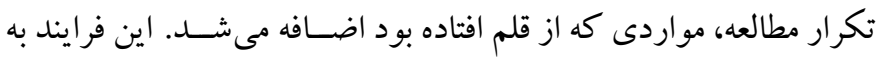

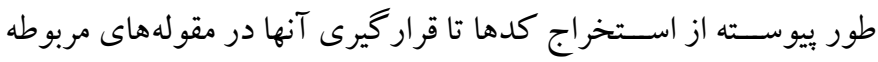

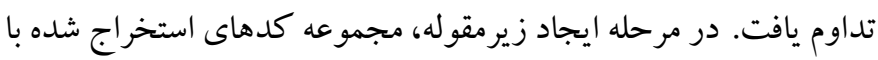

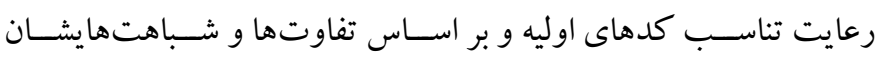

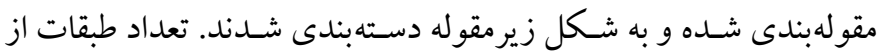
طريق گروهبندى دادهها كاهش يافت. هدف اصلى از اجراى اين مرحله، ايجاد شــــايطى براى دركك بهتر بديده و توليد دانش در زمينه مورد نظر

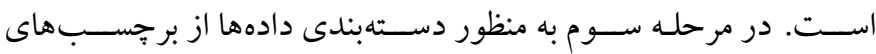

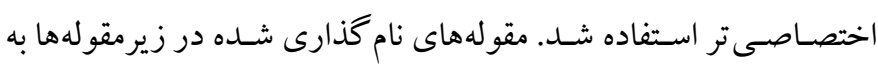

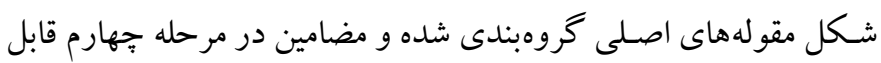

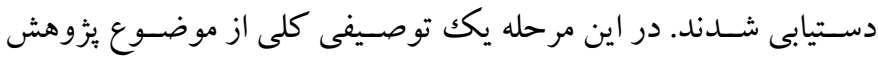

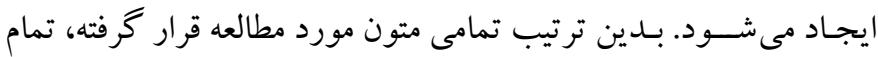
جملات معنادار استخر اج و يادداشتبردارى شده و به هر كدام از مضامين مردي

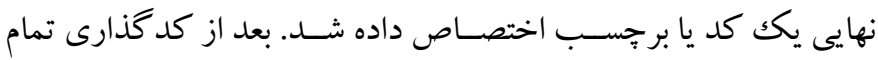

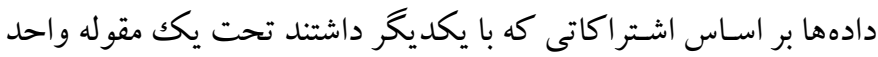

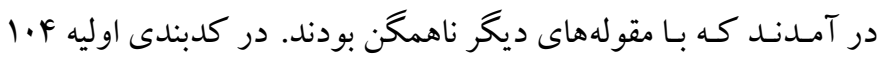

1. Open coding

2. Subcategory 
و مقولهبندى ( • (r): با توجه به ينج مؤلفه ويز گى هاى برنامه درسسى از قبل

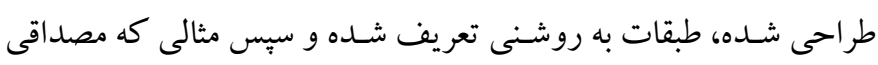

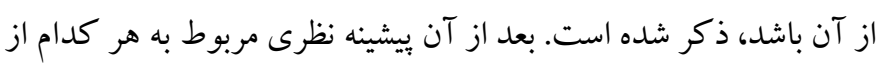

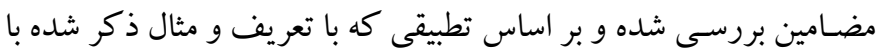

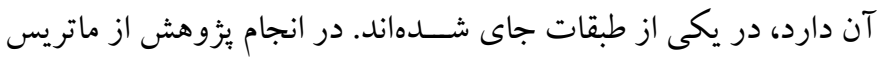
سـاخت يافته با روى آورد قياسـى بهره اسـتفاده شــده اسـت. بدين منوال

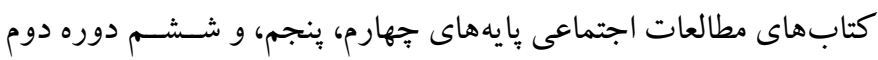

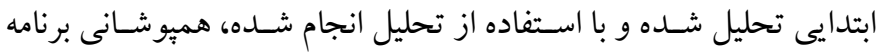

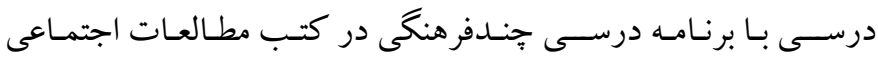

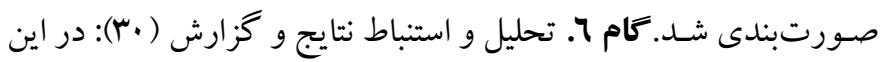
يزّوهش براى تجزيه و تحليل دادهها روش كيفى(توصسيفى ـ تفسـيرى)

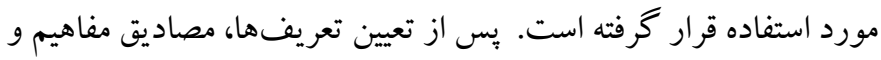

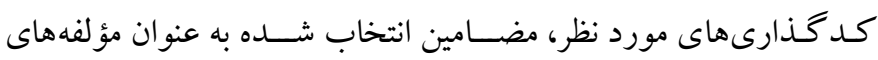

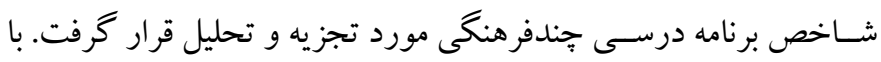

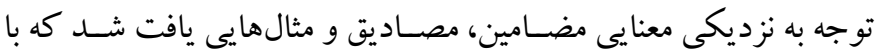

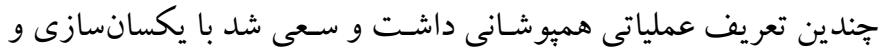
تعديل در يكى از مقولهها قرار گيرد. حاصـل بثزوهش بدين شـرح اسـت

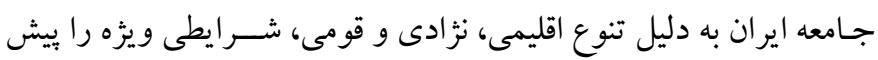

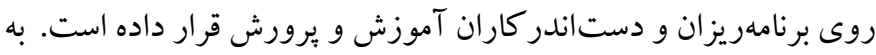

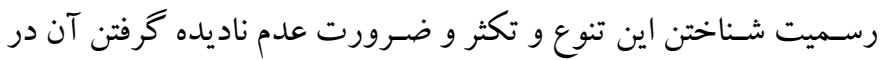
سـاختار و بافتار برنامه درسى آموزش و يرورش از بديهى ترين مطالبات

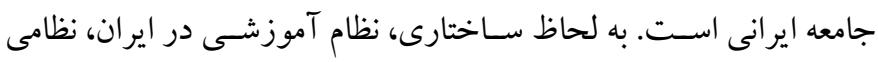

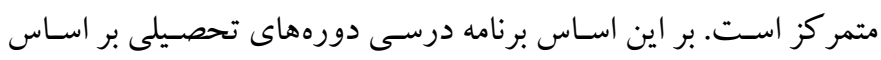

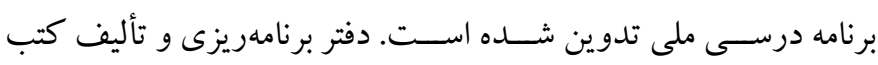
درسى عهدهدار تهيه و تدوين راهنماى برنامه درسى براى تمامى عناوين

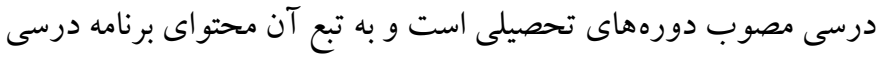

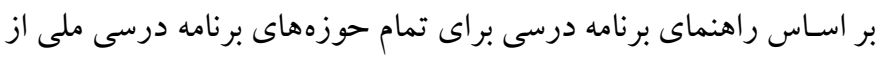

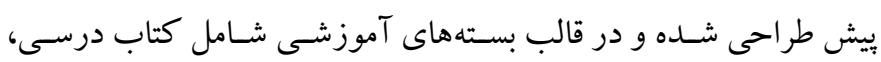

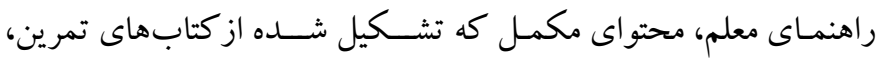

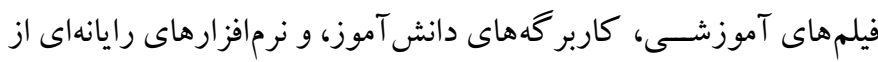

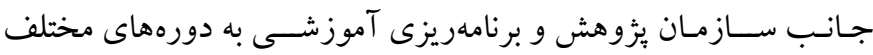

اجتماعى بايههاى سـوم، جهارم، بنجم، و شـشــم دوره دوم ابتدايى را به

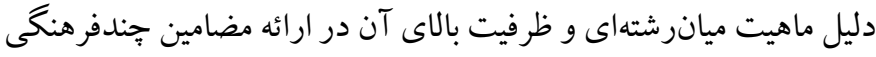

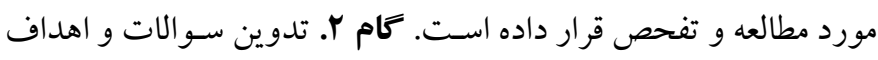
(r.r): بخش دوم يُزوهش با هدف شناسايى ميز ان هميوشانى برنامه درسى

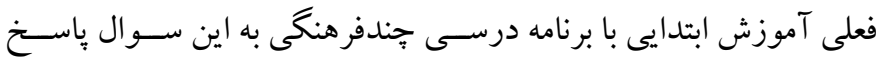

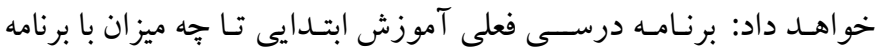

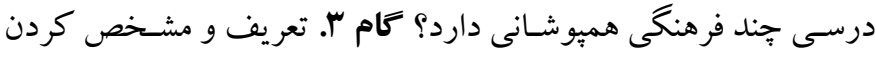

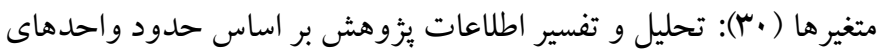

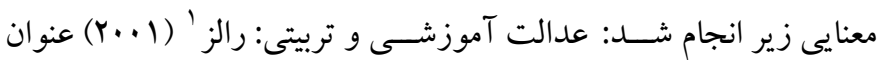

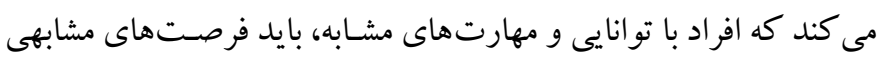

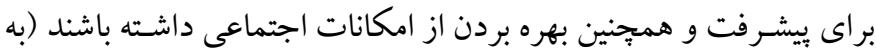

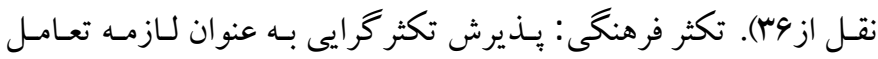

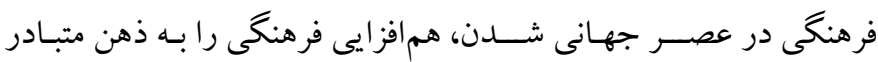

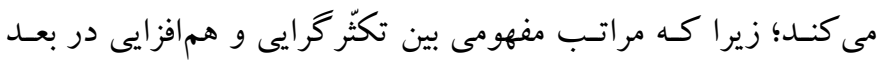

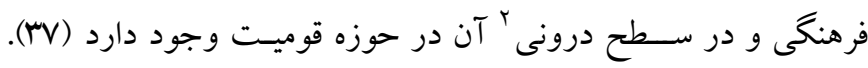

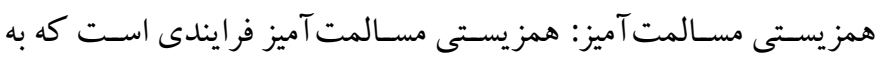

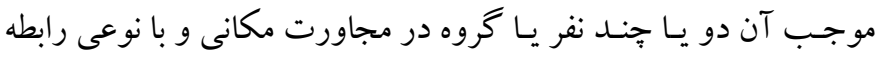

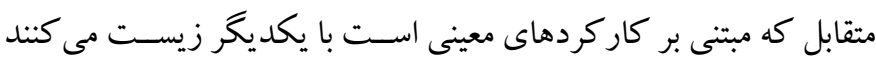

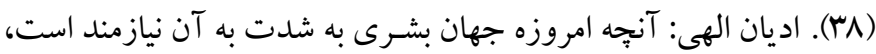

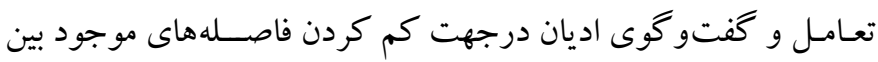

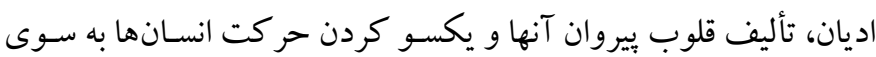

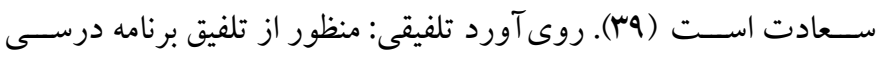

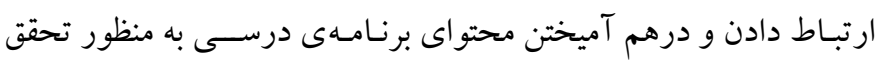

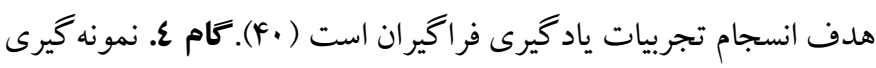

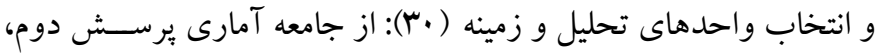
كتابهاى مطالعات اجتماعى دوره دوم از اين رو مورد توجه قرار كرفتند

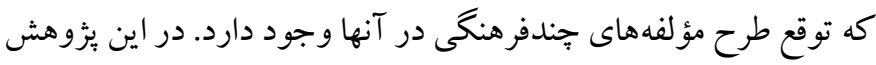

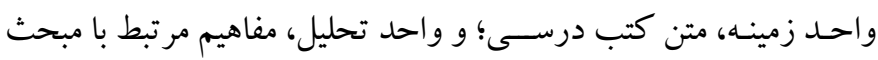
جندفرهنگ سياهه تحليل محتوا بوده است. همجنين در تجزيه و تحليل دادهها، روش وش

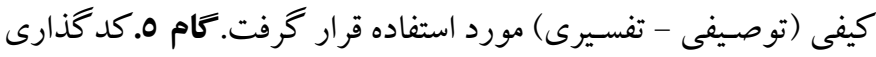


از نوع اسـتقرايى تبيين شـده اسـت؛ به اين صـورت كه با استفاده از روش تحليل محتواى كيفى از گونه اسـتقر ايى، يثروهشـر به سـازماندهى داده هاى كيفى برداخت. فرايند انجام كار شـامل كد كذارى آزاد، ايجاد طبقه له يافته ها وزيرطبقه يافتها و استتخراج معنا است. كد كذارى اوليه، به ايجاد سب مقوله اوليه منجر شد و در مراحل بعدى اين مقولات با يكديخر مقايسه شـده و تعدادى از آنها كه نزديكى بيشـترى داشستند زيرمجموعه مقولات عـامترى قرار كرفتنـد. تعـداد آنها با زيرمقوله بود كه هر يكك از اين مقولات ميانى معرف يكك بخش يا طبقه خاص از موضسوع بيزوهش بود.

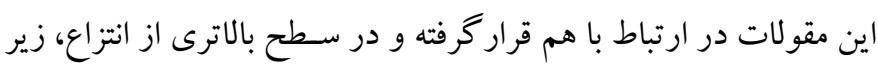
ه مقوله اصلمى جمع شـدند كه در نهايت مضامين اصلى را تشكيل دادند. نتايج تحليل انجام شده در جدول سارائه شده است.
تحصسيلى عرضسه مىشـود. اين يثروهش به بررسسى و تفحص در محتواى برنامه درسـى مطالعات اجتماعى در قالب راهنماى برنامه درسـى، كتاب درسـى، راهنماى معلم و كاربر كهاى دانش آموزى برداخته اسـت. دليل انتخـاب درس مطـالعـات اجتمـاعى، دارا بودن ظرفيت ميانرشــتهاى اين درس در ارائه آموزش هاى جند فرهنى است.

\section{يافتههاى ثزوهش} الف) يرسـش ا: بر اسـاس اصـول تعليم و تربيت آموزش ابتدايى، برنامه

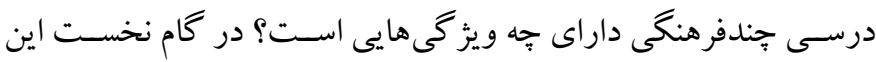

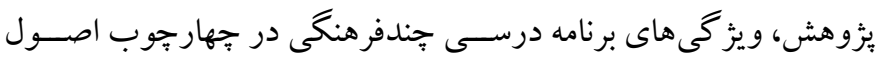
تعليم و تربيت آموزش ابتدايى با اســفاده از روش تحليل محتواى كيفى

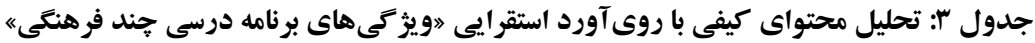

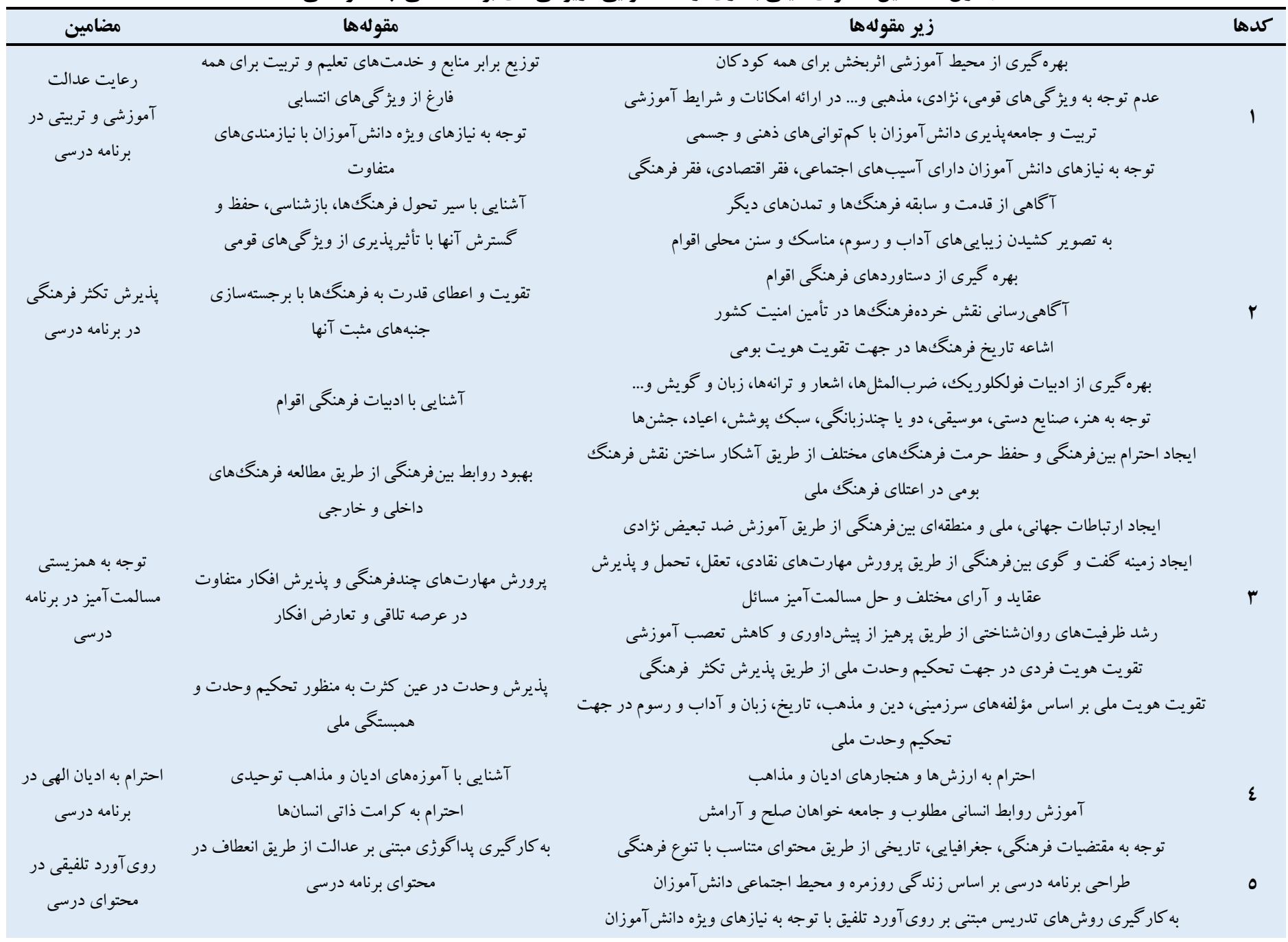




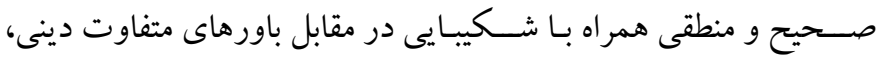
احتر ام بـه ارزشهـاى اخلـاقى و انســانى اديان در مواجهه با موقعيت هاى

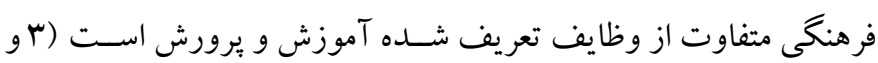

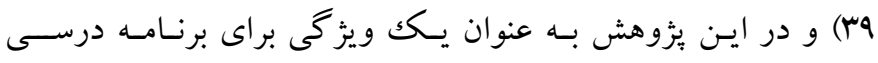

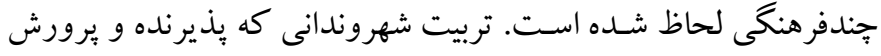

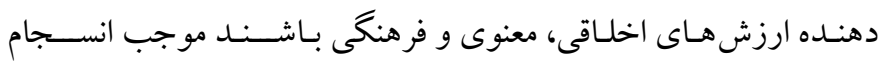

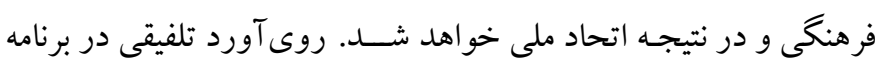

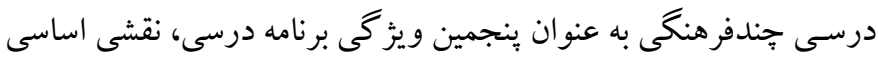

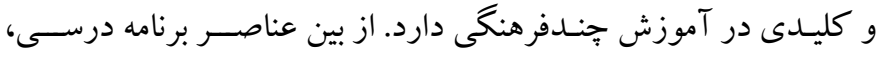

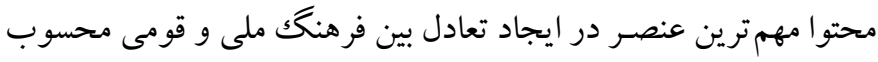

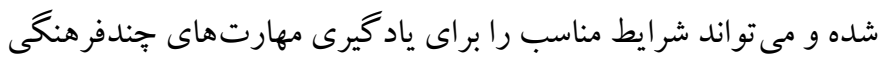

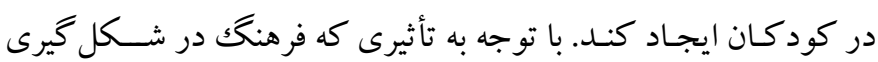
شـخصيت كود كان دارد، موقعيت تحصيلى دانش آموزان به ميز ان بسيار

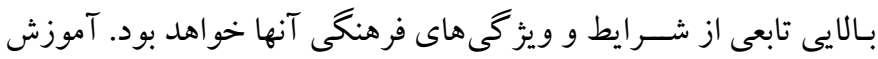

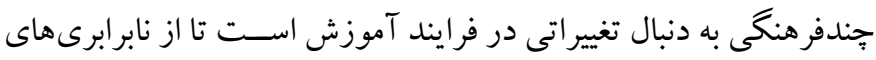

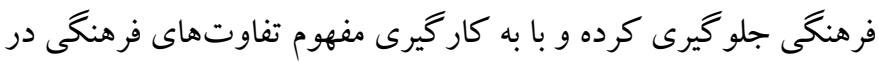

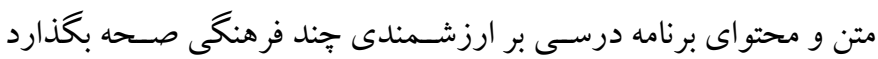
$(f \cdot g \mid f)$ ب) يرسـش rا: برنامه درسسى فعلى آموزش ابتدايى تا جه ميزان با برنامه

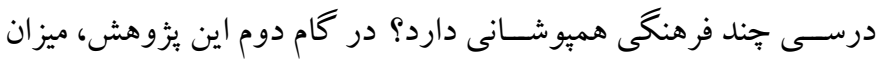

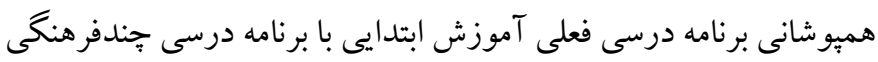

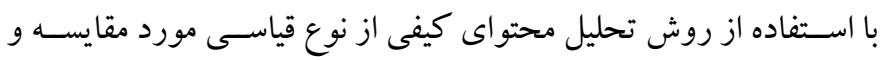

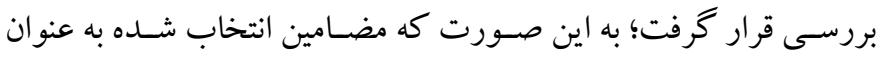

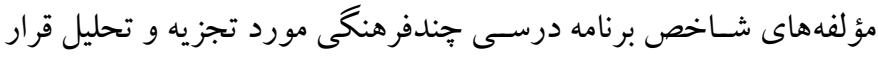

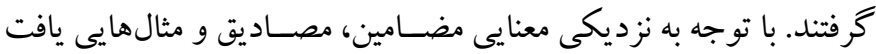

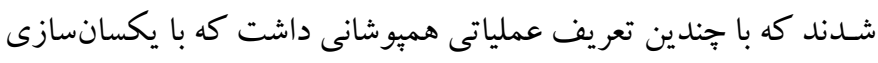

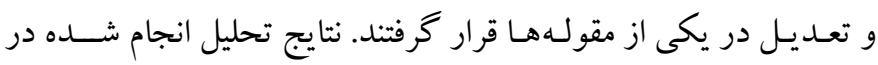
جدول F ارائه شده است.

همان طور كه در جدول ب مشاهده مىشود اولين ويز گى مورد اشاره در برنامه درسسى جِندفرهنكى، رعايت عدالت آموزشى و تربيتى اسـت.

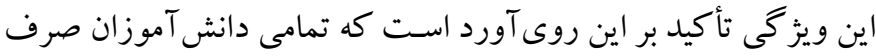
نظر از خروهى كه به لحاظ مليت، طبقه، مذهب، جنسيت يا تو انايى به آن تعلق دارند بايد از برابرى فرصستهاى آموزشـى در مدرسـهـ برخو ردار

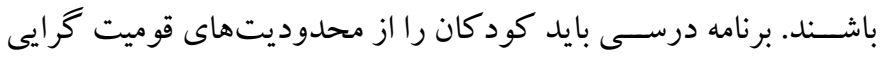

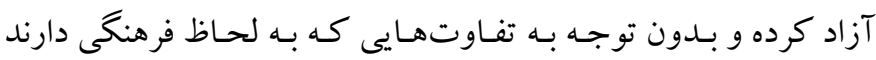

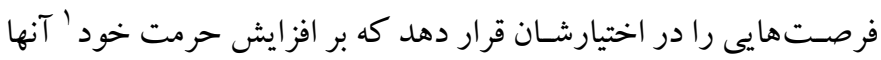

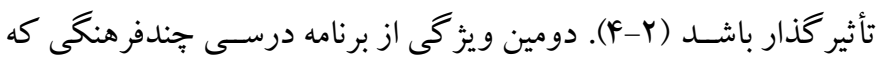

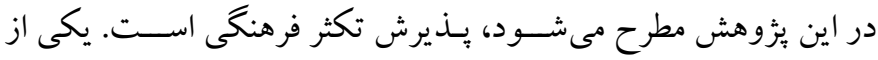

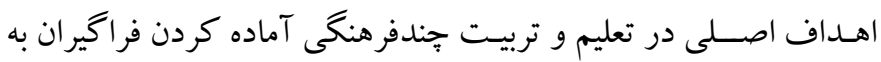

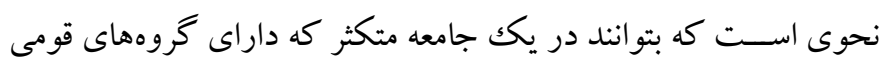

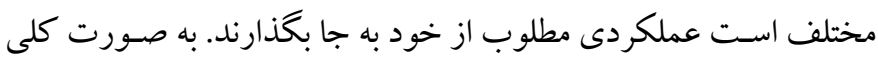
در عصـر حساضـر بـه دليل تنوع اجتماعى، افكار عمومى و گفتتمانهاى

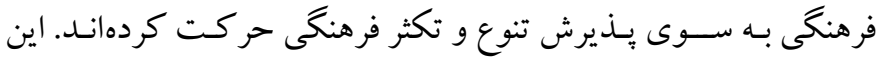

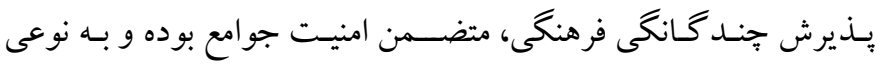

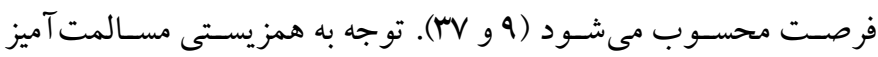

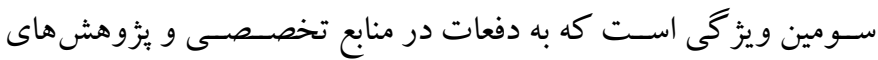

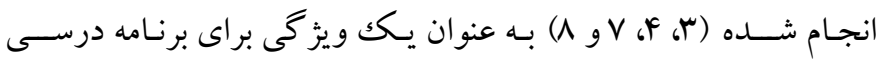

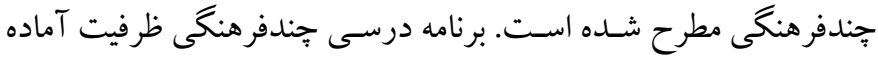

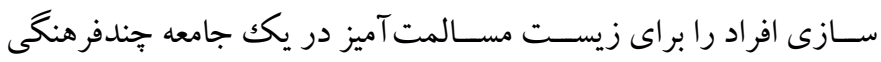

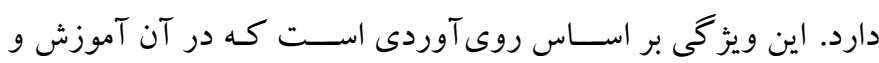
برورش را به عنوان نهادى معرفى مى كند كه بايد با ايجاد تعامل، تفاهم و

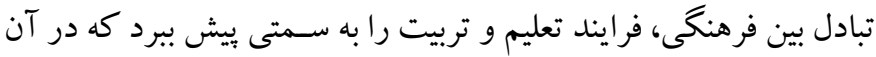

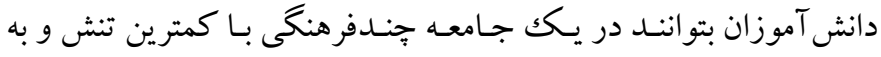

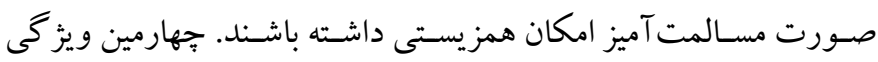

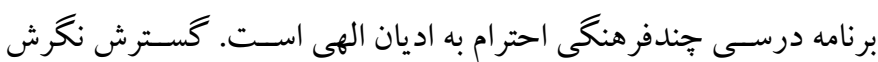

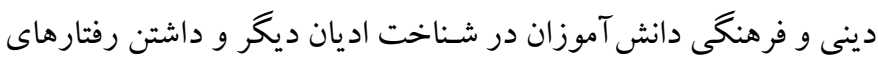

1. Self-esteem 
جدول ع: ماتريس مفهومى تحليل محتواى قياسى 》طبقه بندى، تعريف و كد گذارى مضمون ها《

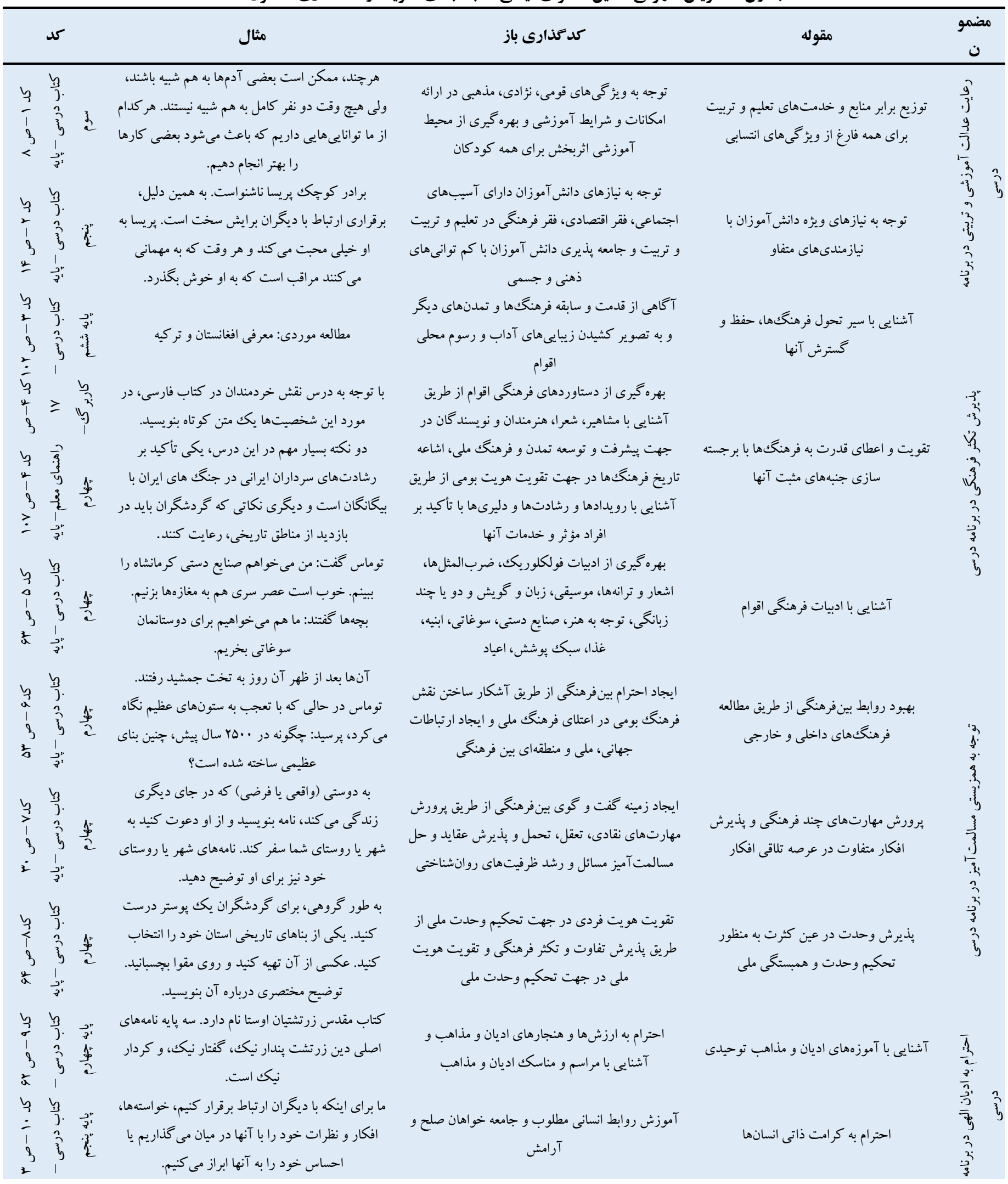




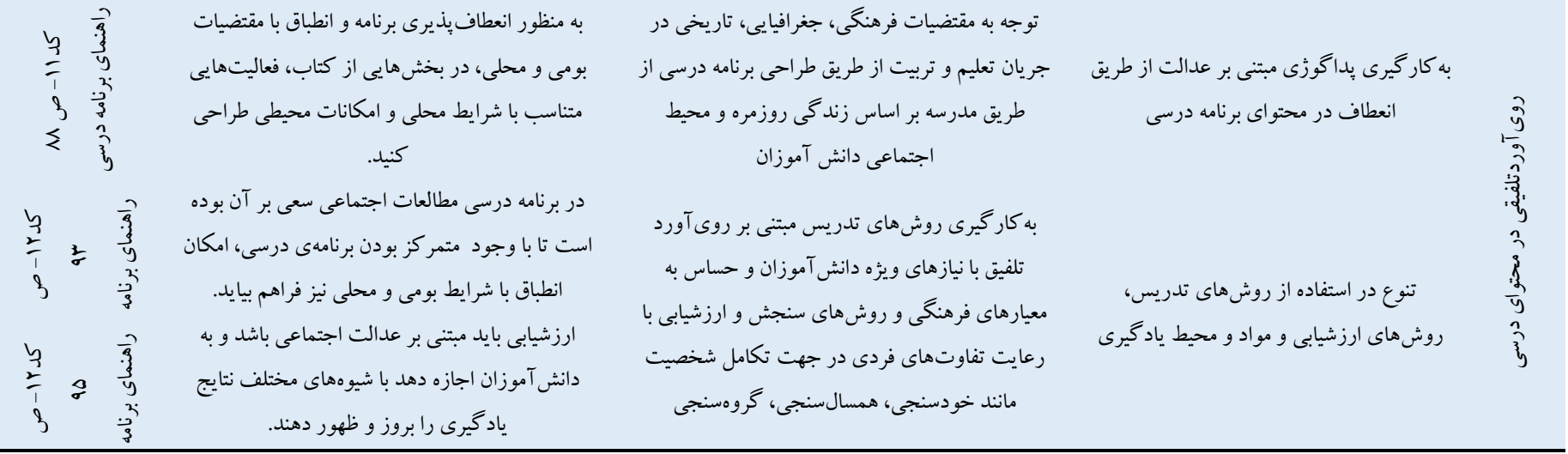

و با هم زيستن)" عنوان كرده اسـت. در صففحه سا راهنماى برنامه درسى تعـاريف جـامعى از اين درس ارائسه شــده كـه با مضــامين جندفرهنكى هميوشـانى قابل توجهى دارد. در اين راهنما يكى از اصـول خاص حاكم بر برنـامـه درســى مطـالعات اجتماعى را امكان تطبيق دروس با شــــايط زندكى دانش آموزان و مقتضــيات محلى عنوان مى كند و به نقش تاريخ در هويتبخشى و نقش مفاخر و شخصيتها و آثار و جلوههاى شكوفايى تمدن و فرهنگك تأكيد مى كند. در سـازماندهى محتوا، روى آورد تلفيقى را مطرح كرده و بر اســاس اسـتفاده از الخوى محيط هاى توسـعهيابنده آموزش در يايه هاى بالاتر به ســوح ملى، قارهاى و جهانى تمايل مىيابد و در زمينه فرايند ياددهى ياد كيرى، روى آورد محتوا، كاوشـرى اسـت. در محورهاى اصسلى برنامه درسـى مطالعات اجتماعى، به تقويت عزت و هو يت اسـلامى ايرانى اشــاره شــده و فرهنگ و هويت به عنوان يكى از راهبردهـاى موضــوعى با مفاهيم كليدى تعلق و هويت، ميراث فرهنكى، تنوع فرهنگ ها، و شــيوههاى زندكى مورد تأكيد قرار گرفته اســت. در

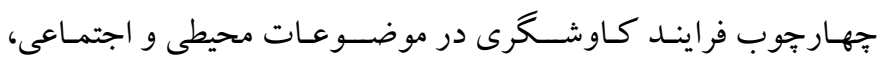
مهارتها در ينج حوزه بررســى و كاوش، برقرارى ارتباط، مشــاركت، خلاقيت، واكنش شخصى، و اظهارنظر در انواع اجتماعات محلى، ملى، و جهانى مورد تأكيد قرار كرفته و در زمينه برورش مهارتهاى مشستر كك با

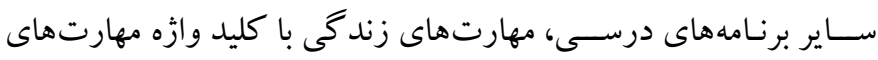
شـــهرونـــى، در فراينـد درونى كردن ارزشهـا، مفـاهيم عـدالـت جويى، حتىطلى، مسـؤيت بذيرى و مشـار كتطلبى، و ميهن دوسـتى را در همان
همان طور كه در جدول F مشـاهده مىشـود ينج مضـمون اسـتخراج شده در سوال يكم اين يثوهش در بسته آموزشى مطالعات اجتماعى براى جهار ســال آخر دوره ابتدايى مورد تحليل محتوا قراركرفتند. مطالعات يثزوهشـحر بر اسـاس كميت و كيفيت كد كذارىهاى باز، ميزان توجه به

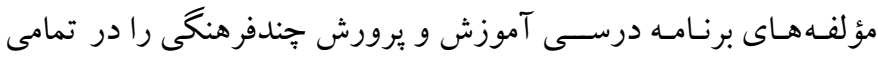
يايه ها ضـعيف نشـان مىدهد؛ هر جِند ميز ان بردازش به مضـامين يكسـان نبوده و فراز و فرود داشـه اسـت. ازآن جا كه دو منبع اصلى مطالعه براى ياسـخ به اين سـوال يزٔوهش، راهنماى برنامه درسى دفتر يزٔوهش و كتاب و راهنماى معلم درس مطالعات اجتماعى بايههاى سـوم تا شـشم بوده، در اين بخش از يافتهاى يزٔوهش، در همين دو محور به توصـيف مطالعات يزووهشــر درباره ميز ان هميوشـانى محتواى بســـه آموزشـى مطالعات اجتماعى با مؤلفه هاى برنامه درسى جند فرهنگى برداخته شده است. الف. راهنماى برنامه درسـى مطالعات اجتماعى در صــفحه V (راهنماى برنامه درسسى مطالعات اجتماعى، دفتر برنامهريزى و تأليف كتب درسـى وزارت آموزش و يرورش)، جهـت كيرى درس را تربيـت شــهرونسدى مطرح كرده اســت. اين راهنمـا كـاربرد روشهـاى تلفيقى را بـا توجه به مبانى روان شـناختى ' فراكيران توصيه كرده و يكى از اهداف اختصاصى برنامه را (اتحول و اصـلاح برنامههاى درسى دورههاى مختلف تحصيلى با

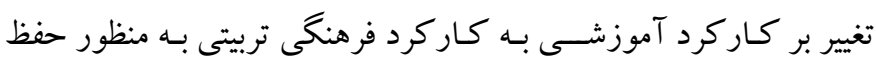

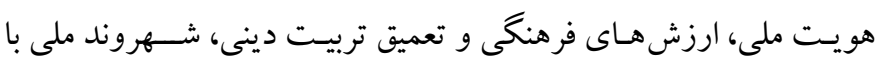
مناسـبات جهانى، توسعه مهارت هاى دانايى، استقلال سازنده، مفيد زيستن

1. Psychological 
فرهنكى محســوب مى شـــود. ايجـاد ار تباط با جوامع بين المللى، ملى، و

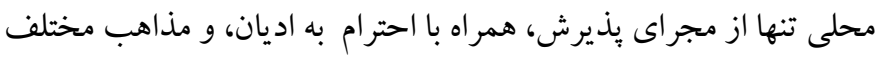

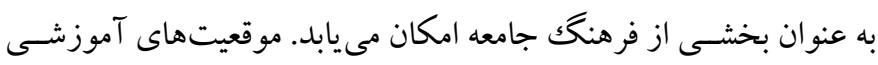

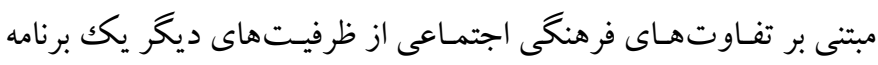
درسى جندفرهنكى است. سبك تدريس و ارزشيابى مبتنى بر يكك برنامه

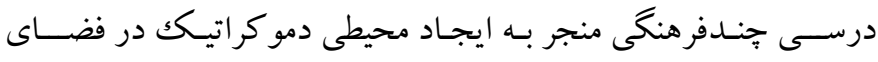

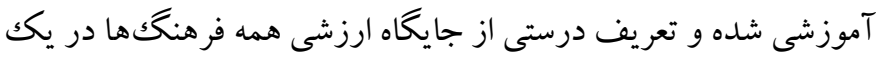

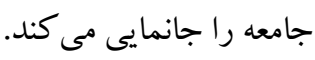

\section{بحث و نتيجل}

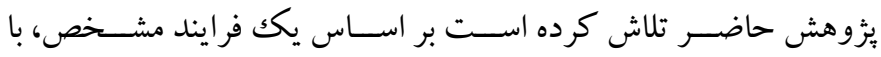

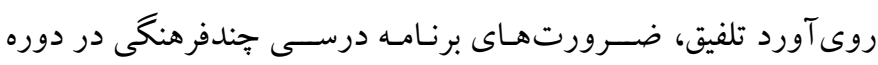
ابتدايى را تبيين كند. در اين فرايند براى يرسش نحرى نحست، بر اساس مطالعه

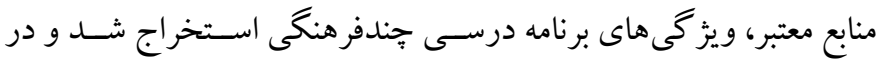

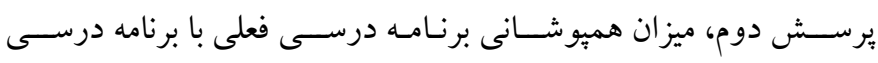

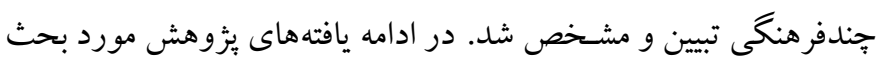
قرار مى گيرد:

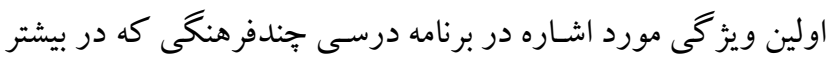

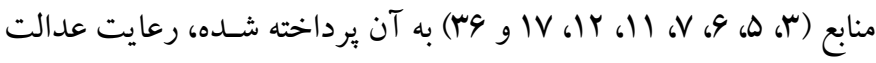

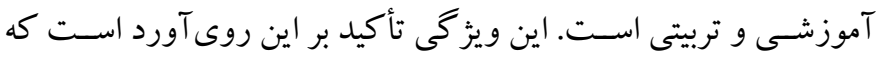

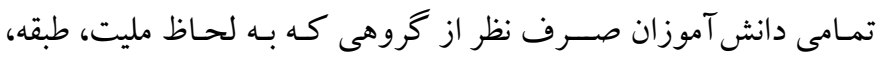

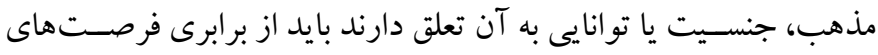

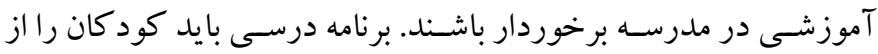

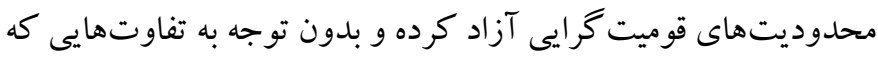

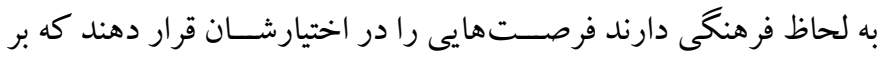

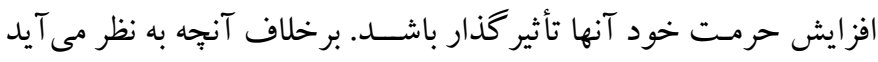

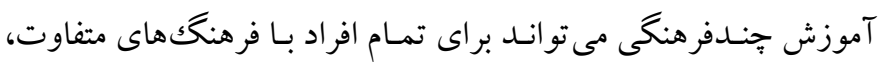

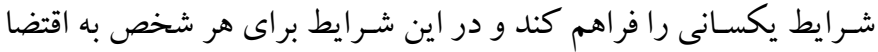

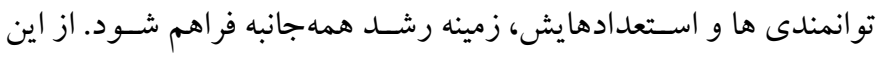

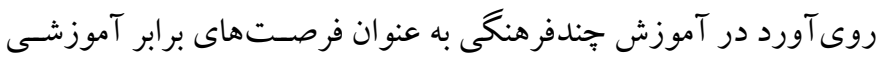

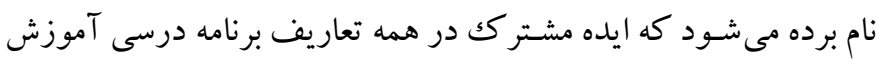

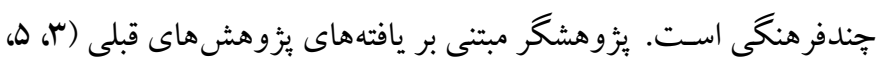

سطوح مطرح مى كند. درباره توليد بسته آموزشى در صفحه 9 (راهنماى

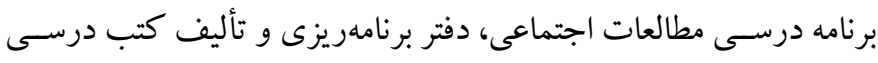

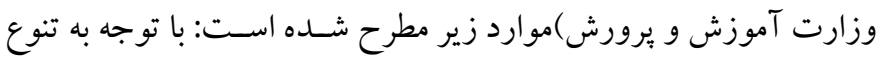

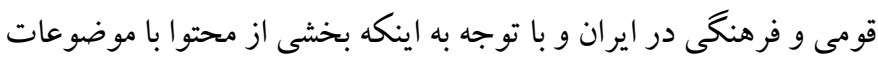

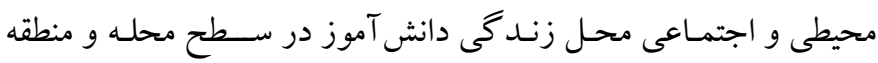

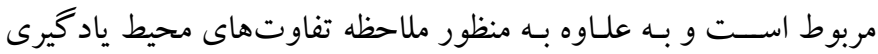
دانش آموزان، لازم است تمهيدات و تدابيرى جهت تهيه و توليد بستههاى

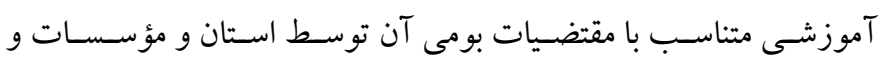
نهادهاى ذيربط محلى، اتخاذ و از ميزان تمركز در اين زمينه كاسته شود. دربـاره انجام فعاليتهاى كتاب در صـفحه M M (راهنماى برنامه درسـى مطـالعـات اجتمـاعى، دفتر برنـامسهريزى و تـأليف كتـب درسـى وزارت

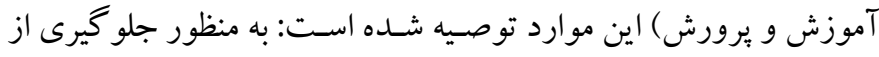

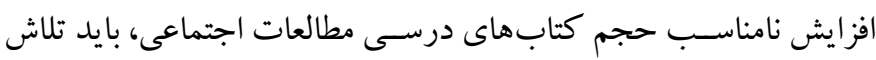

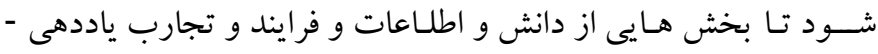

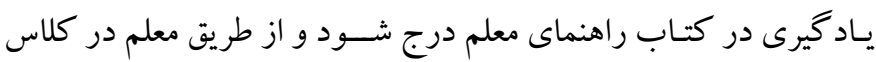

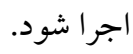
ب. در كتـاب درسـى و راهنمـاى معلم بـه لحاظ محتو ايى در مضــمون

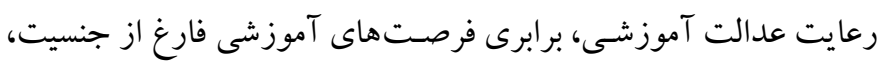

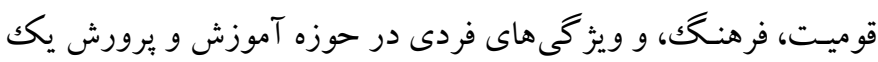

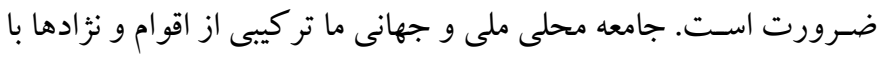
فرهنك ها و باور هاى مختلفى اسـت كه كاه بســيار با هم فاصــله دارد.

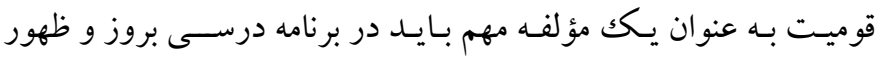

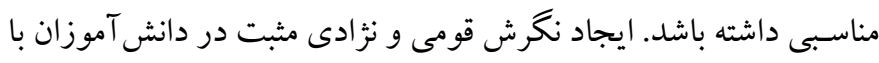

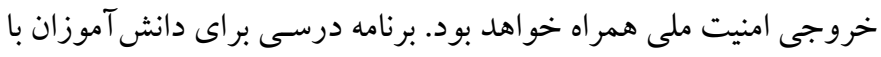
ويز گى هاى جسمى و ذهنى متفاوت هم بايد داراى حساسيت و روى آورد

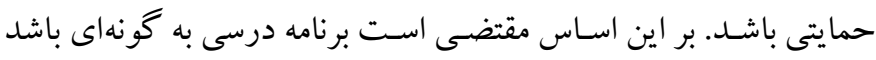

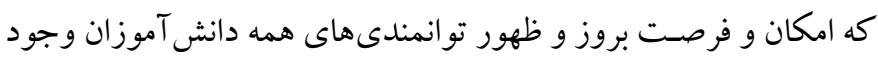

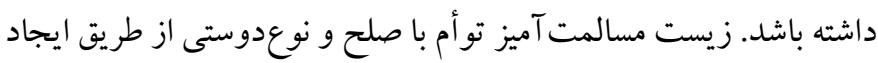

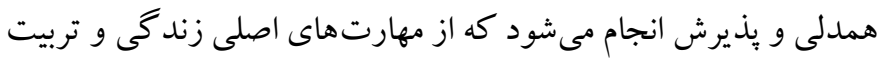

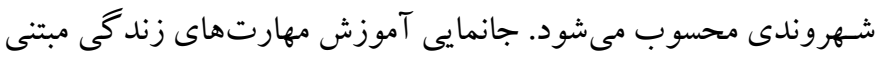

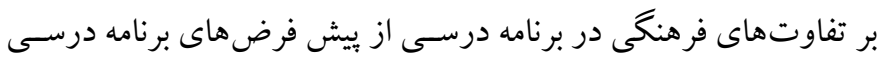

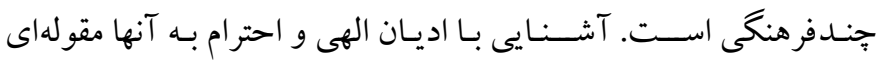


يكك جامعه جندفرهنگى دارد. اين ويز گى بر اسـاس روى آوردى اسـت

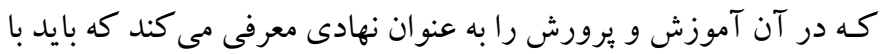

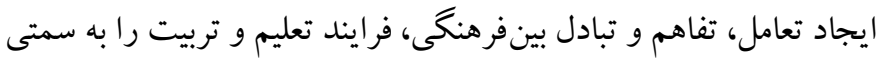

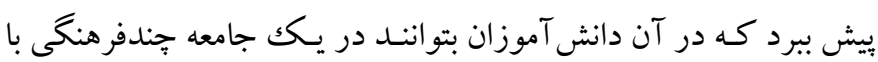
كمترين تنش و به صورت مسالمت آميز امكان همزيستى داشته باشند. در برد

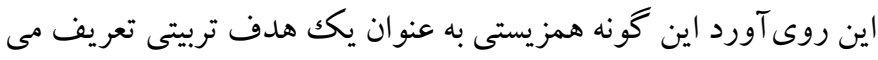
شـود. جنين برنامه درسـى خو اهان ترويج صـلح و دوســى ميان افراد و

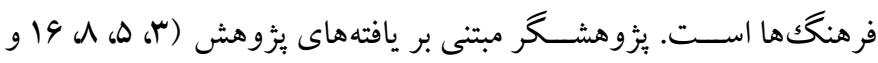

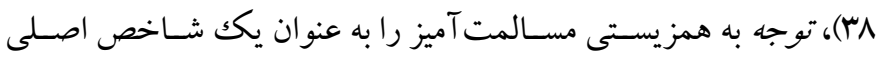

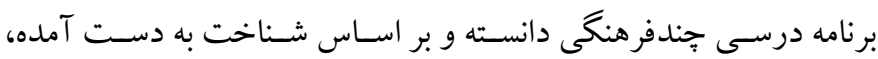

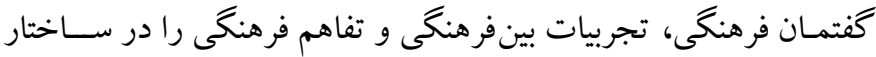
برنامه درسى ضرورى دانسته است.

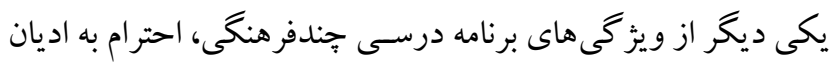

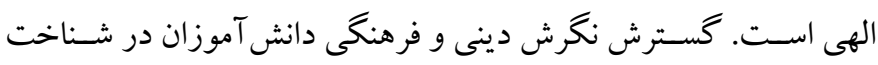

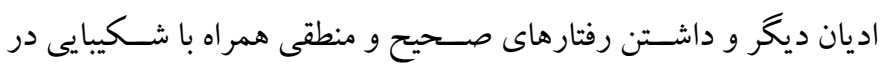
مقابل باورهاى متفاوت دينى، احترام به ارزشهاى اخلاقى و انسـانى اديان

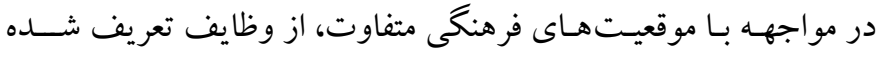

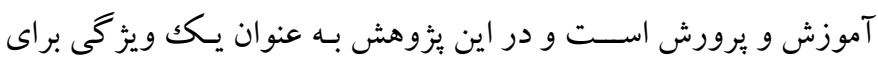

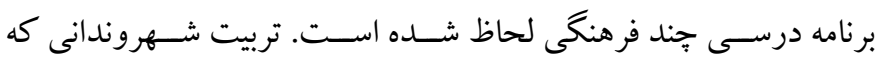

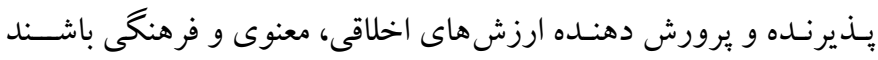

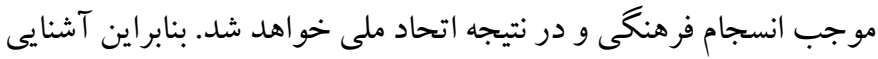

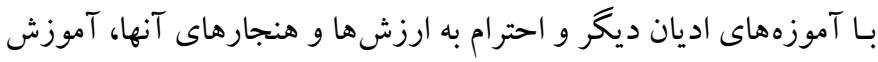

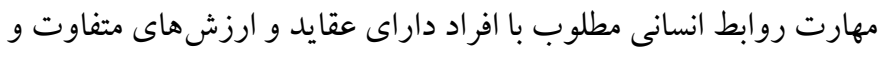

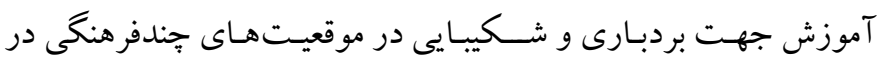

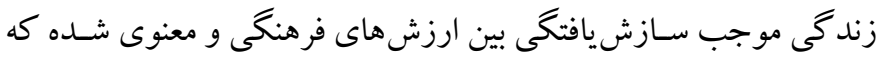
بى ترديد آموزش و يرورش در اين گسـتره، نقش كليدى و اسـاسى ايفا

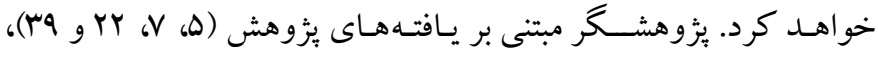

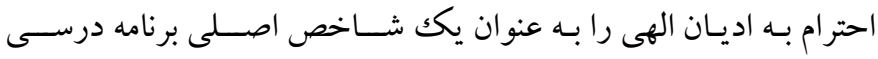

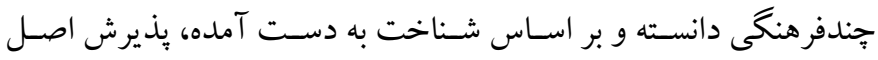

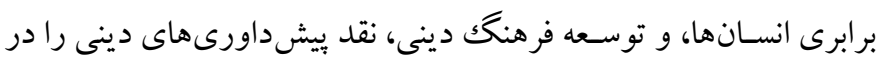

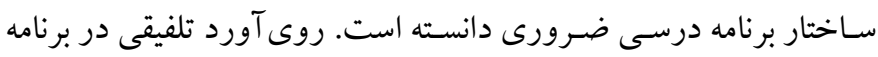

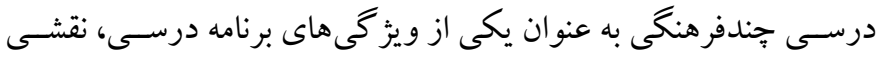

Yا، (T و و T)، رعايت عدالت آموزشى و تربيتى را به عنوان يك شاخص

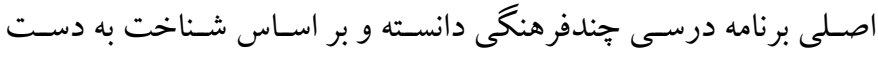

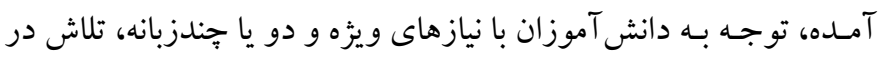

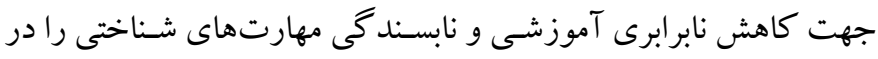

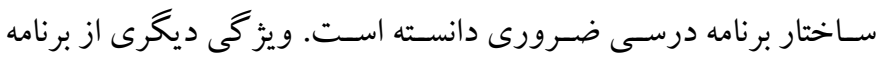

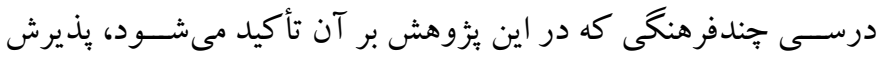

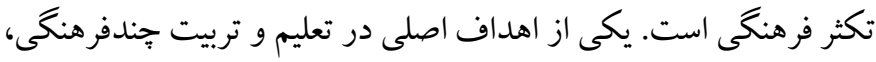

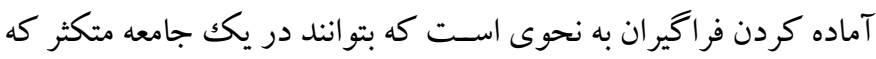

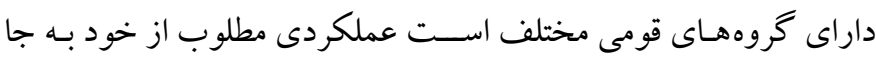

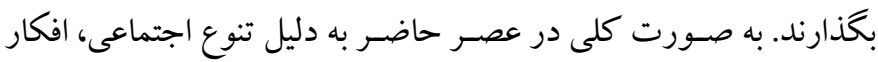

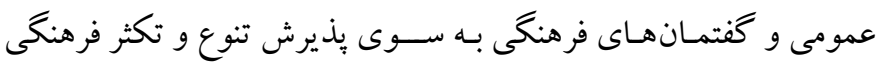

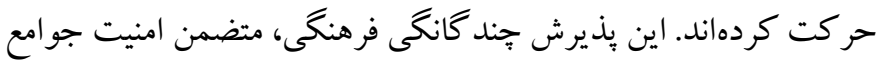
بوده و به نوعى فرصـت محســوب مى شــود. به دليل جلو گيرى از بروز

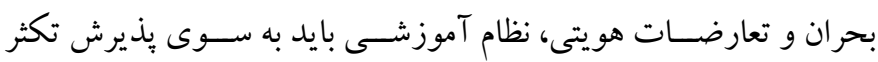

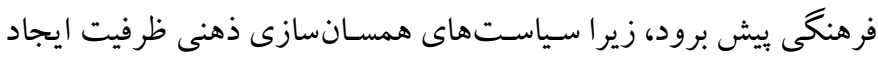

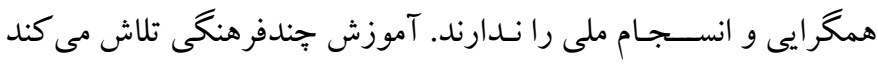
جايگاه كثرت كرايى فرهنكى را برجسـته كرده و براى نيازهاى آموزش

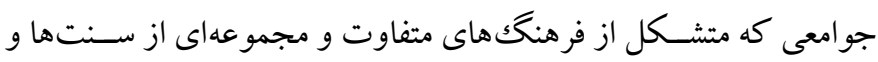

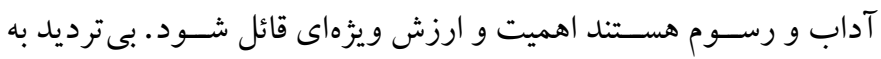

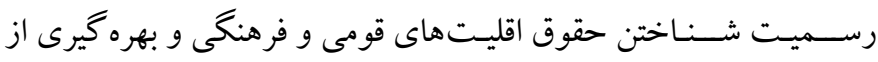

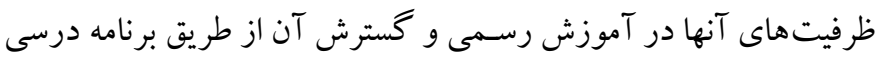

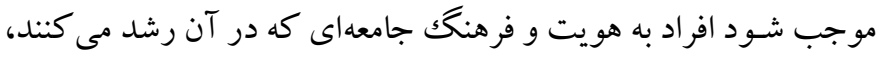

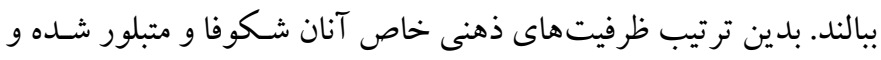

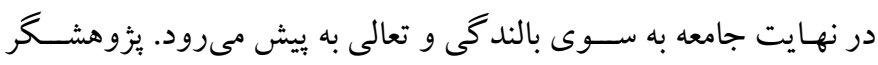

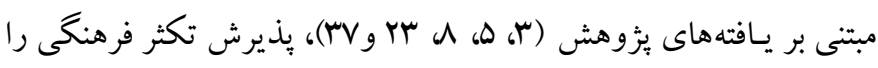

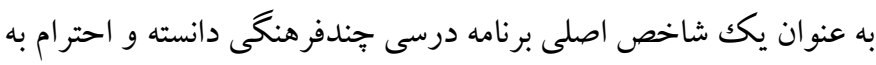

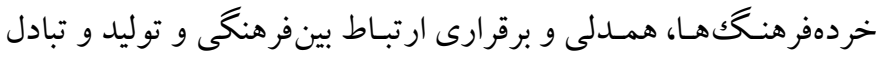

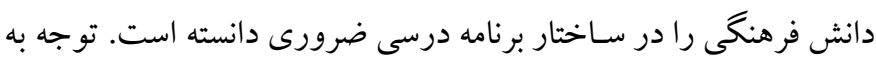

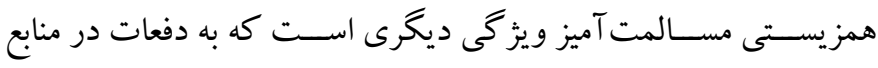

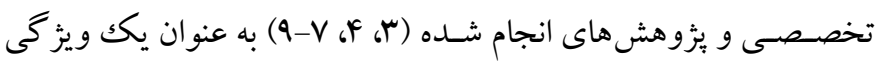

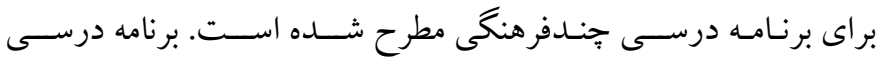

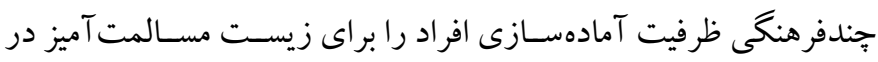




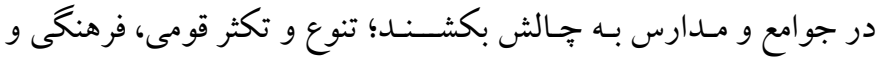

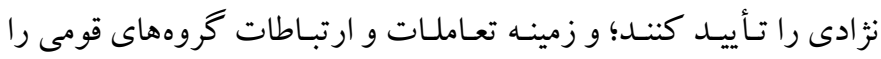

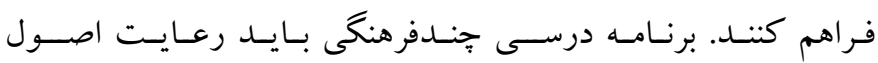

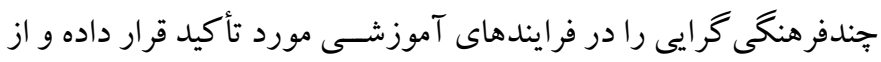

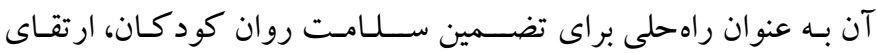
سازش يافتكى هاى اجتماعى و شكل گيرى هويتهاى سازش يافته در آنان

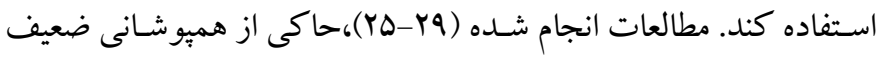

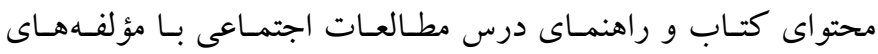

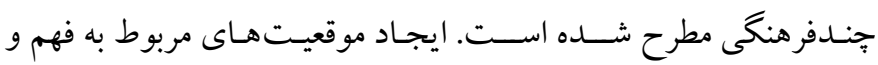

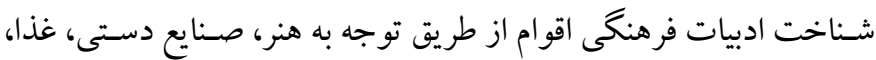

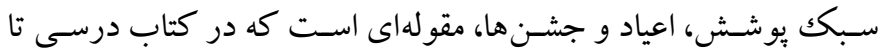

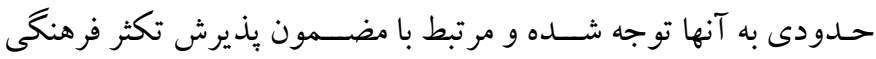

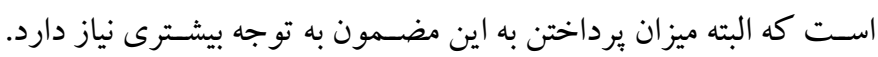

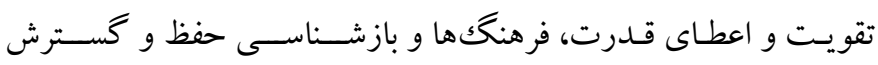

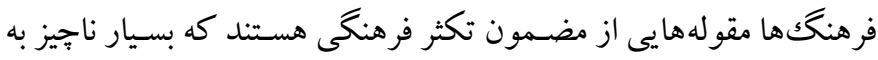

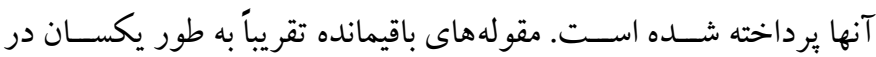

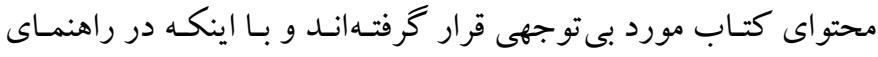

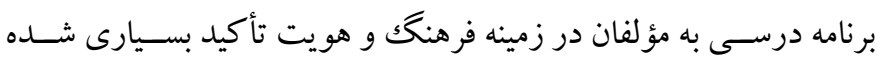

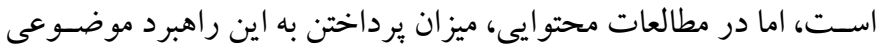
بسيار كم توصيف مى شود. مطالعات نشان از هميو شانى ضعيف محتواى

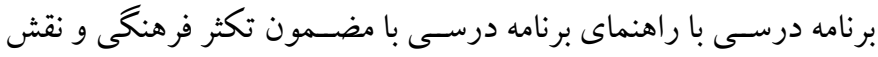

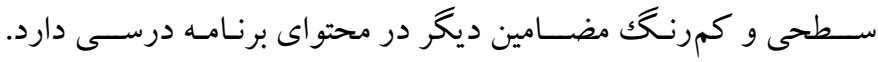

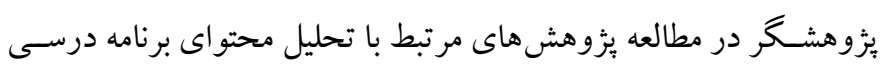

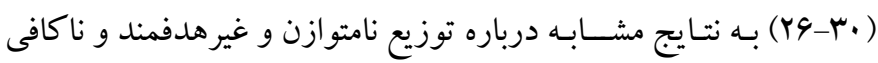

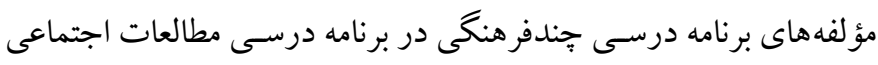

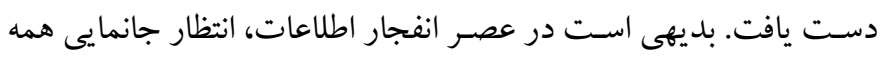

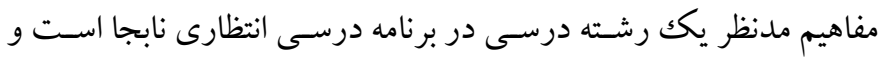

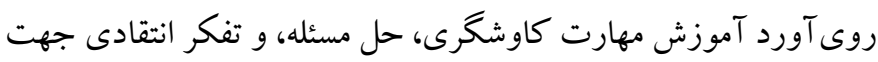
ارائه محتواى برنـامـه درســى علوم اجتمـاعى، تلـاشـى در جهـت رفع محدوديت مطرح شده است.

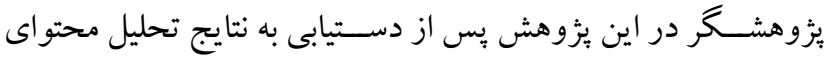

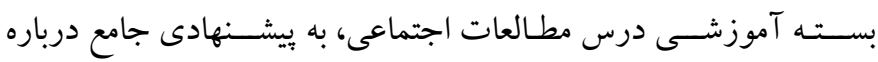

اسـاسى در آموزش جندفرهنكى دارد.از بين عناصـر برنامه درسى، محتو ا

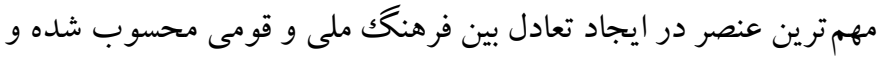

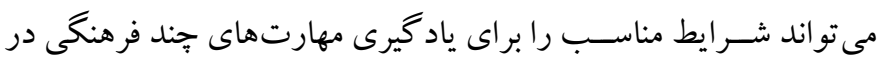

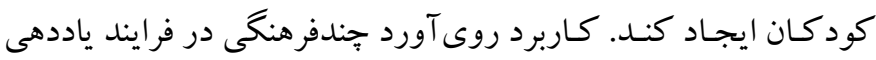
ياد گيرى به صورت كاربردى در محيط واقعى آموزشى، توصيه بسيارى

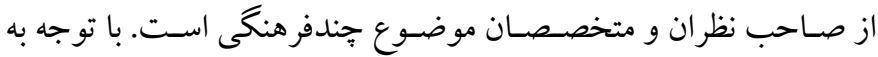
تأثيرى كه فرهنگك در شـكل گيرى شــخصـيت كود كان دارد، موقعيت

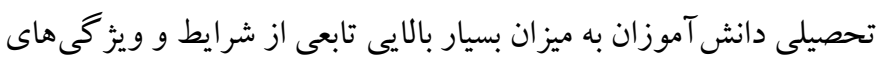

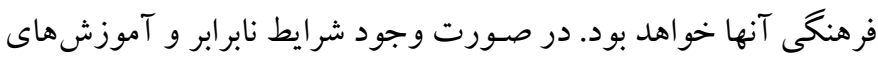

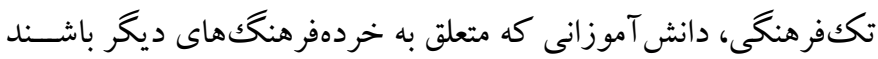

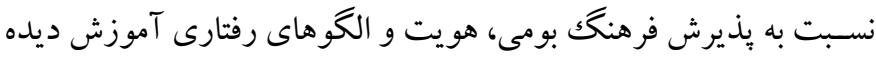

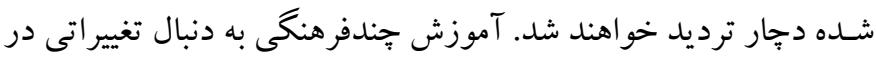

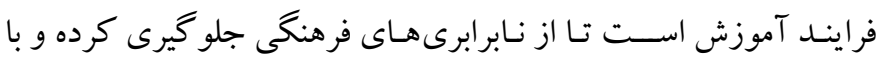

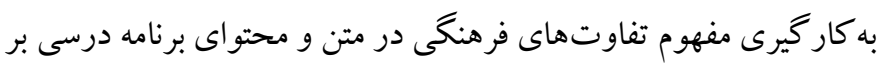

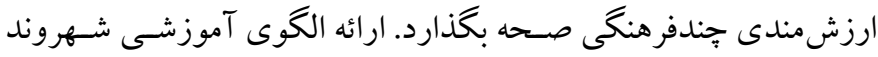

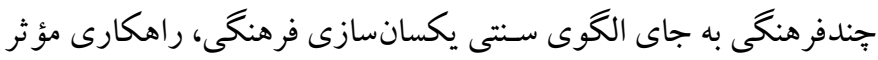

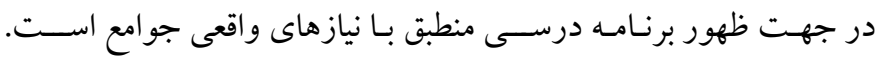

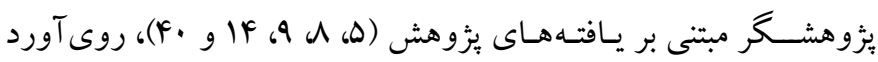

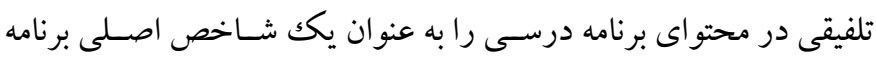

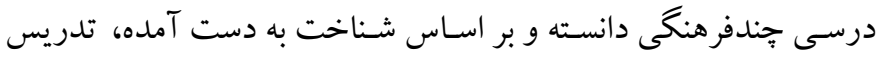

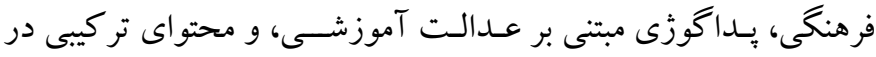
برنامه درسى را در ساختار برنامه درسى، ضرورى دانسته است.

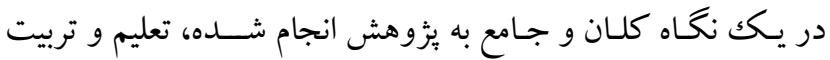

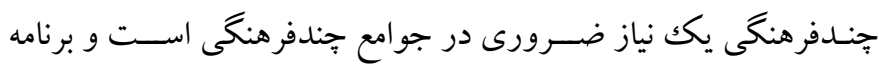

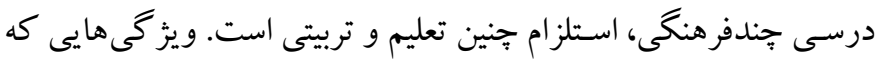

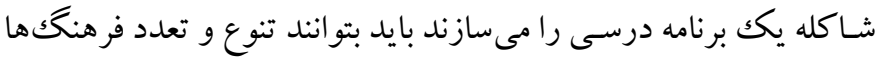

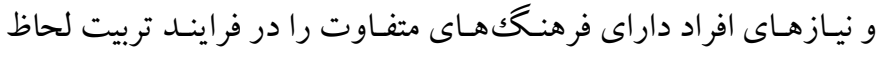

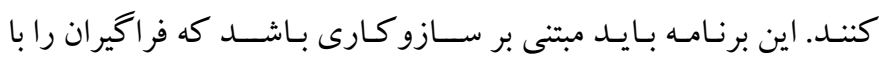

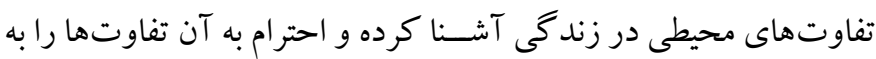

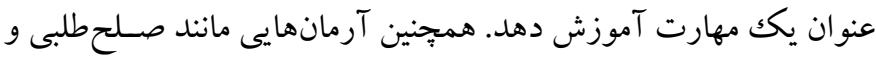
همزيستى مسـالمت آميز و نوع عوستى به عنوان بر جسته ترين آرمانها در

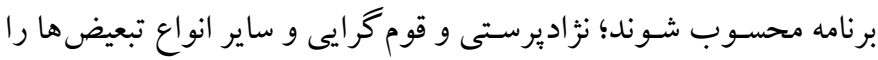




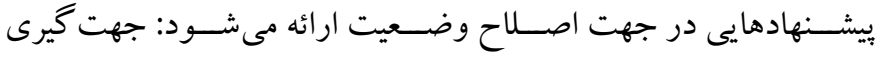

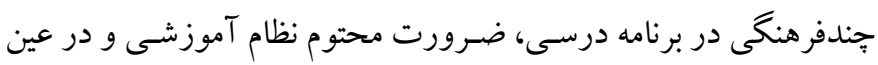

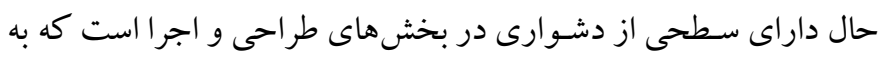

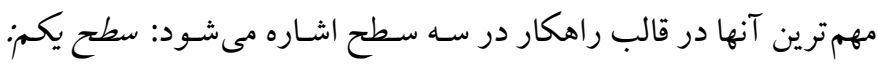

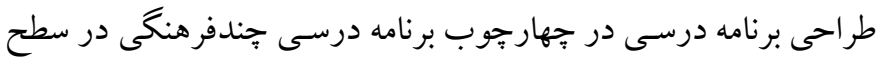

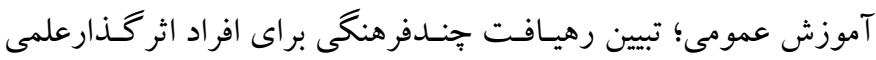

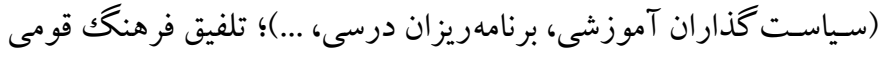
و ملى در محتواى برنامه درسـى؛ و تربيت مدرســان ميانى داراى مهارت

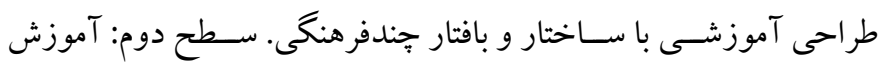
مهارت روش تدريس جندفرهنكى به معلمان؛ آموزش مهارت شـيوهوهاى

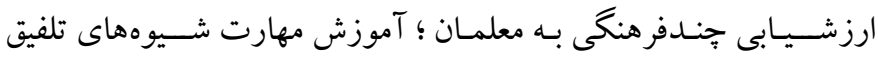

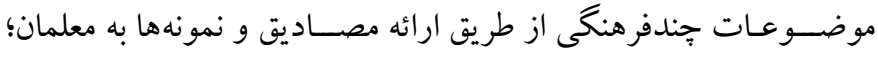

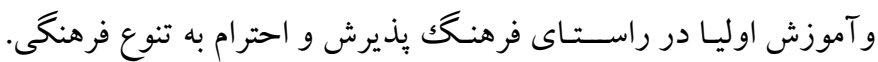

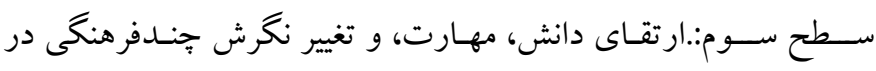

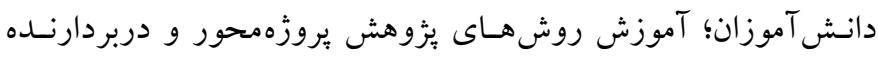

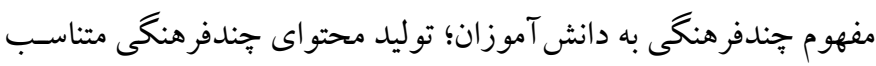

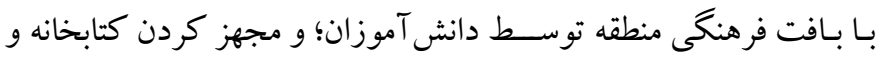

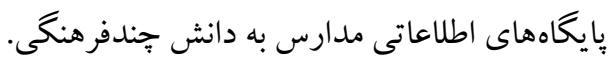

ملاحظات اخلاقى وييروى از اصـــول اخلـاق يخوهش: اين مقـاله بركرفته از رســاله دوره دكتراى

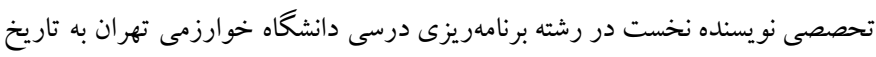

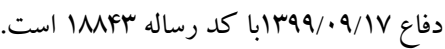
حامى مالى: اين مطالعه بدون حمايت مالى هيج مؤسسه و سازمانى انجام شده است. نقش هر يكك از نويسـند كان: نويسـنده نخسـت به عنوان نويسنده اصلى اين مقاله و

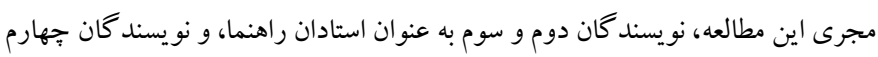
و ينجم به عنوان استادان مشاور در اين مطالعه نقش داشتهاند. تضاد منافع: در اين يزوهش هيج گُونه تعارض منافع توسط نويسند كان كزارش نشده تشكر و قدردانى: بدين وسيله از تمامى افراد و مؤسساتى كه در انجام اين يثروهش

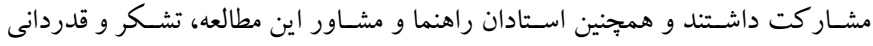
مىشود.

آموزش مهارت هاى مؤثر در تربيت شـهروندى بر اسـاس توزيع متوازن

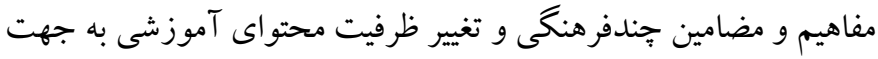

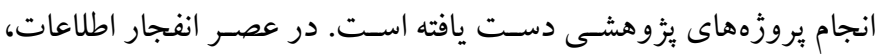

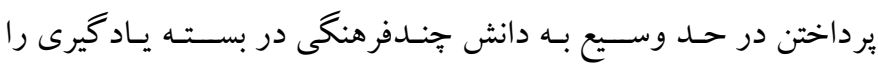

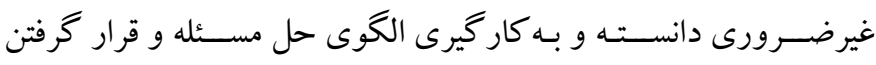

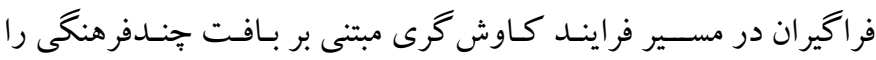
بيشـنهاد كرده و ضـمن ارائه مثال هايى در جدول ماتريس مفهومى تحليل

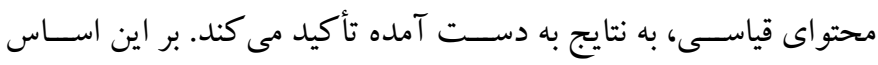

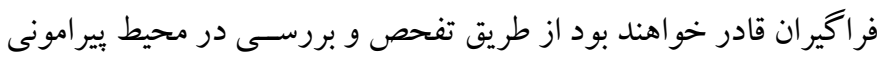

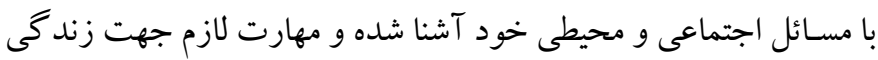
شـهرونـدى در صـلح و امنيت را كسـبـ كنند. برنامه درسـى بايد در روى آورد اصسلى خود بر كثرت گگرايى فرهنگ و و برابرى تأكيد كند و از

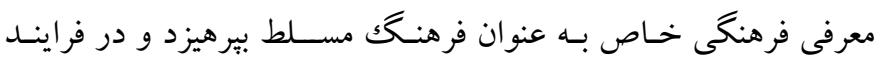

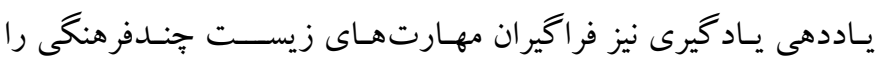

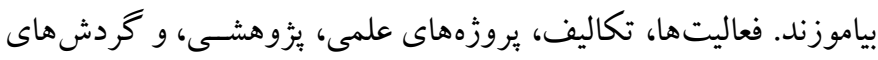

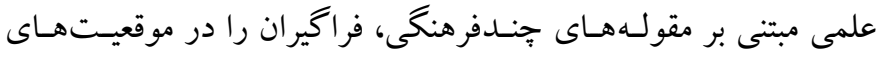

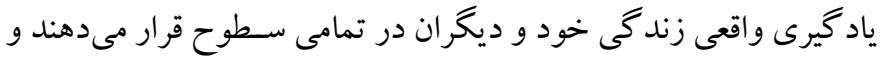

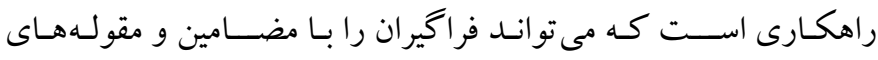

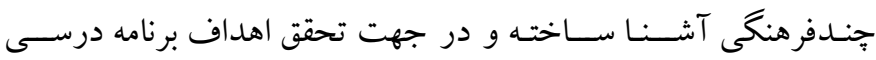

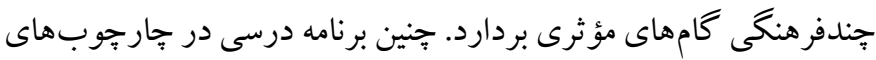

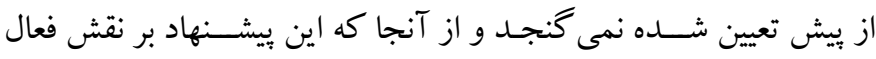

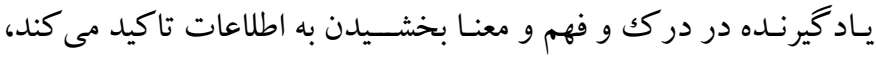

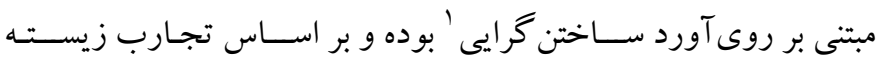

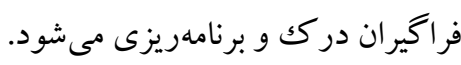

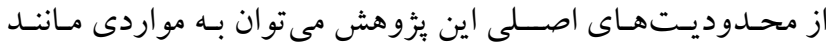

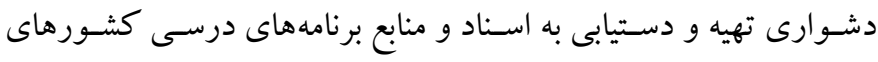

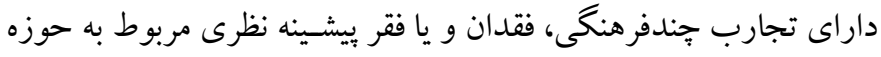

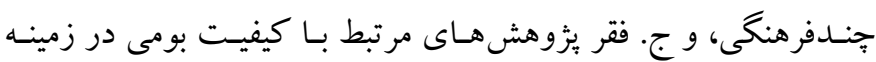

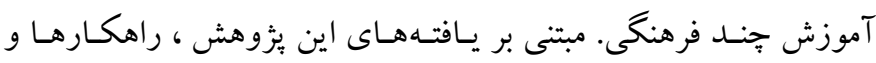

1. Constructivism 


\section{References}

1. Banks J., McGee Banks C. Multicultural Education: Issues and Perspectives. New Jersey: Wiley; 2019, pp: 6. [Link]

2. Tavassoli T. Cultural Pluralism and its Effects on EducationalSystems.Journal of philosophical theological resrarch site and its.2019;4(78):166-189. [Persian]. doi/10.22091/PFK.2019.2669.1785 [Link]

3. Sadeghi, A.-Characteristics and Necessities of Developing a Multicultural Curriculum in Iran; Review of Challenges, Presentation of Strategies. Quarterly Journal of Culture Strategy, 2012; 5(17-18): 93-121. [Persian]. [Link]

4. Daryaii N.Ethics and cultural heritage. Quarterly Journal of Ethics in Science and Technology, 2016; 11(2):19-28 [Persian]. [link]

5. Sadeghi A.Multiculturalism and its relation to education. Educational Technology Development Monthly. 2012; 28 (228): 34-37. [Persian]. [Link]

6. Sadeghi A.Study of the National Curriculum Document of the Islamic Republic of Iran based on the multicultural education approach. Iranian Curriculum Studies Quarterly. 2010; 5 (18): 189-214. [Persian]. [Link]

7. Demir N., Yurdakil B. The Examination of the Required Multicultural Education Characteristics in Curriculum Design. Procedia - Social and Behavioral Sciences. 2015; 174: 3651-3655. doi.org/10.1016 /j.sbspro.2015.01.1085. [Link]

8. Macroni G., Boland Hemtan K. Multicultural education in elementary school textbooks. Journal of Shahid Chamran University of Ahvaz. 2014; 6( 1):7392. [Persian]. [Link]

9. Soltani S, Adib Y, Mahmoodi F, Vahedi S. The position of a curriculum based on the multiple intelligences in the textbooks of the first grade of primary school based on the components of multiple intelligences. J Child Ment Health. 2020; 7(1): 270280. http://dx.doi.org/ 10.29252/ jcmh.7.1.23. [Persian]. [Link]

10.Suryaman, Juharyanto. The Role of Teachers in Implementing Multicultural Education Values in the Curriculum 2013 Implementation in Indonesia. IISTE Jorunal of Education and Practice. 2020; 11(3): 152156. doi.org/10.7176/JEP/11-3-16 [Link]

11.Misco T.Culturally Responsive Curriculum and Pedagogy in the Commonwealth of the Northern Mariana Islands. International Journal of Multicultural and Education. 2018; 20(2): 81-100. DOI: http://dx. doi.org/10.18251/ijme.v20i2.1575 [Link]
12.Zilliacus H., Holm G., Sahlström F. Taking steps towards institutionalising multicultural education The national curriculum of Finland. Multicultural Education Review. 2017; 9(4): 231-248. doi/full/10.1080/2005615X.2017.1383810 [Link]

13. Sadeghi A.Reviewing the National Curriculum of the I.R. of Iran Using a Multicultural Approach. Journal o f Curriculum Studies (J.C.S.) .2010; 5(18): 190-215. [Persian]. [Link]

14.Araghiyeh A., Fathi Vajargah K., Foroughi Abri A., Fazeli N. Combining the right strategy to develop a multicultural curriculum. Journal of Integrated Studies in the Humanities. 2009; 2 (1): 149-165. [Persian]. [Link]

15.Abdul Ali Sultan Ahmadi J.Investigating the level of attention to design and development of multicultural curricula in the Iranian education system from the perspective of curriculum specialists. National Conference on Multicultural Education.2013. [Persian]. [Link]

16.Arslan H., Raţă G. Multicultural Education: From Theory to Practice. Newcastle:Cambridge Scholars;2013, pp25 [Link]

17..Lightner S. Multicultural Curriculum and Teaching in the Standards-Based Classroom. Multicultural Perspectives. 2018; 20(2): 126-130. Doi.org/10. 1080/ 15210960.2018.1447195 [Link]

18.Ahmadi P., Sobhaninejad M., Amiri M .Interdisciplinary Organization of the Curriculum with Emphasis on Effectiveness of Courses Content. Teaching and learning research.2015; 12(1): 97-122. [Persian]. doi/10.22070/2.6.97 [Link]

19. Malekipour A. , Hakimzadeh R. Explanation of multicultural curriculum with emphasis on identifying the national and indigenous components of curriculum, international identity. Quarterly Journal of Qualitative Research in Curriculum, Allameh Tabatabai University. 2016; 1 (4): 41-45. Doi/10. 22054/QRIC.2016.7492. [Persian]. [Link]

20. Mohammadi Sh, Kamal Kharazi S., Kazemi Fard M, Pourkarim J. Provide a model for multicultural education in the higher education system: Analyze the views of experts in this field in Iran. Journal of Teaching and Research.2016; 4 (1): 65-91. [Persian]. [Link]

21.Abdul Ali Sultan Ahmadi J., Sadeghi A. Design and validation of a multicultural curriculum model for the general education course in Iran. Curriculum Studies . 2015; 10 (39): 71-108. [Persian]. [Link] 
22. Araghiyeh A., Fathi Vajargah K. Position of Multiculturalism in School Education and Higher Education .2012; 5(17-18): 187-204. [Persian]. [Link]

23. Asgarian M. Place of ethnic cultures in educating citizens. Educational Innovations .2006; 5(3): 133162. [Persian]. [Link]

24.Azizi N., Bolandhemmatan K., Soltani M. A study of multicultural education in teacher training centers in Sanandaj from the perspective of students. Iranian Higher Education Quarterly. 2010; 3 (2): 55-78. [Persian]. [Link]

25.Babeli Bahmaei A, Yar Mohammadian M, Yuzbashi Z. Content analysis of the seventh grade social studies book based on the index (components) of multicultural extracted from upstream documents. National Conference on Multicultural Education.2013; 74-75. [Persian]. [Link]

26.Jokar, H. Multiculturalism in Book VI of Social Studies; The philosophy of multicultural curriculum and the extent to which it is reflected in textbooks. Social Science Education Growth .2017; 20(1): 13-17. [Persian]. [Link]

27.Chaharbashloo H, Safaei M, Roshan Ghiyas A., Abdi A. Analysis of the content of social studies textbooks in elementary school based on the components of multicultural education. Fourth Annual Conference of the Iranian Curriculum Studies Association, Culture and Curriculum. 2016; Bu Ali Sina University of Hamadan. [Persian]. [Link]

28.Eini A., yazdani H., Sadeghi A. a content analysis of social Science Textbooks of 4th, 5th, 6th grades within the items of multicultural education. Research in Curriculum Planning .2018 :15(58): 136-151. [Persian]. doi/10.30486/JSRE.2018.543735 [Link]

29.kayhan J. Analysis of the status of Multicultural Education in the Content of Social Sciences and Persian Curriculum in Elementary School by Shannon Entropy Method. 2015; 4(1): 79-95. [Persian]. [Link]

30. Momeni rad A.Qualitative content analysis in research tradition: nature, stages and validity of the results. Quarterly of Educational Measurement. 2013; 4(14): 187-222. [Persian]. [Link]

31.Hayati N., Hejazi R., Hosseini S., Bastani S. Extraction of Environmental Indicators from the
Board of Directors' Report, Using Qualitative Content Analysis. Empirical Research in Accounting .2018; 7(4): 43-70. [Persian]. doi/10.22051/ JERA.2017. 16466.1729 [Link]

32.Tabrizi M. Analysis of qualitative content from the perspective of deductive and inductive approaches. Social Sciences Quarterly.2014; 21(64):105-138. [Persian].

33. Mohammadpour A. Quality Assessment in Qualitative Research: Principles and Strategies of Credit and Generalizability.Social Sciences Quarterly.2010; 17(48):73-107. [Persian]. [Link]

34.Havas Beigi F., Sadeghi A., Maleki H., Qaderi M. Multicultural education in Persian textbooks (reading) Iran primary education course. Two Quarterly Journal of Theory and Practice in Curriculum. 2018; 6 (11): 141-174. [Persian]. [Link]

35.Nik Nafas S., Aliabadi KH.The role of content analysis in the process of teaching and designing textbooks. World Media Magazine .2013; 8 (2): 124150. [Persian]. [Link]

36. Yari Qoli B. Investigating the place of education and educational justice in John Rawls' theory of justice. Quarterly Journal of Modern Educational Thoughts. Faculty of Educational Sciences and Psychology, AlZahraUniversity. 2014; 10 (3): 139-172. Doi/10. 220 51/ JONTOE.2015.380 [Persian]. [Link]

37.Rezapour Ghoshchi M, Naderi M.Globalization and Ethnic Pluralism in Iran, challenges and oppertunities. Strategic Studies of public policy. 2015; 5(17): 55-91. [Persian]. [Link]

38. Karimi Maleh A., Moazen M. Cultural diversity and their coexistence in Iran.National Studies Quarterly.2011; 12 (1): 27-47. [Persian]. [Link]

39. Grayley M., Karami F., Karami B. The Imami Jurisprudence and Its Relation with Freedom of Speech. Safir e noor. 2014; 7(28): 27-47. [Persian]. [Link]

40. Yaghouti H., Javadipour M. , Khosravi A. Combining Approach in the Physical Education Curriculum of Elementary School: Explaining the Possibility from the Perspective of Experts. Two Quarterly Journal of Theory and Practice in Curriculum. 2013; 1 (2): 149164. [Persian]. [Link] 